\title{
السرد في شعر احمد رفيق المهداوي
}

أ.م.د. عبد الكريم خضير عليوي السعيدي

كلية التربية الأساسية . جامعة سومر

تسعى هذه الورقة النقدية إلى الوقوف على البنية السردية في شعر أهم شاعر ليبي احيائي، وهو احمد رفيق المهدوي، الذي اخترنا من ديوانه قصيدة ( غيث الصغير ) بوصفها أنموذجاً لشعره السردي، فوقفنا على طرائق البناء الفني لعناصر بنائه السردي ، التي قسمناها على ثناثة أقسام، هي ؛ عناصر الإطار السردي، وتضم عناصر العنوان والخاتمة والاستهلال والحدث الافتتاحي، أما القسم الثاني، فأطلقنا عليه تشمية عناصر البناء السردي، وهي؛ الحدث والزمان والمكان والثخصية، أما القسم الأخير، فأطلقنا عليه تسمية عناصر التشكيل السردي، وهي؛ الراوب المروي له ـ السرد ـ المنظور أو وجهة النظر. الوصف ـ الحوار. 
Seeks paper literary criticism this to stand on the structure of narrative in the poetry of the most important Libyan poet biotransformation, which Ahmed Rafiq Almahdawiy, who chose his poems poem (Ghaith small) as a model for his poetry narrative, we studied the methods of construction technical elements of construction narrative, which made it three sections, namely; elements frame narrative, and includes elements of the title and conclusion and initialization and the inaugural event, while the second section, we called construction elements narrative, namely; event, time, place and personal, while the last section, we called the elements forming the narrative, namely; narrator irrigated his narrative perspective or point of view Description dialogue. 


\section{من هو المهروي ؟ : .}

انه احمد رفيق بن محمد أمين المهدوي، أبوه الحاج محمد أمين المهدوي كان عند مولده قائم

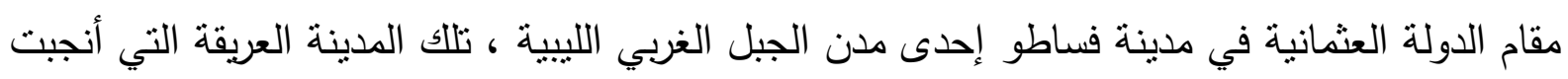
سليمان الباروني أحد قادة الجهاد ضد الإيطاليين كما أنجبت الثيخ أحمد الفساطوي صاحب جريدة المرصاد.

كان مولده في ليلة شتائية باردة عام (191())م في مدينة فساطو الجبلية، وهناك حيث ولد المولود تفتحت عيناه على مناظرها الطبيعية الآسرة ، ومن نسماتها العاطرة امتلأت رئتاه ، وبين أهلها الطيبين كانت نشأته الأولى ، ولكنه لم بطل المكوث في هذه المدينة ، وسرعان ما أنتقل عمل أبيه إلى مدينة جبلية أخرى تقع في أقصى الغرب الليبي ، وهي نالوت التي عمل الأب فيها قائم مقام للسلطات العثمانية ،وفي هذه المدينة مكث المولود سبع سنين ونيف ، تعلم خلالها بعض السور القرآنية وبعض الدروس الأولية ، وييدو أن طبيعة عمل أبيه جعلته يتنقل بين المدن الليبية، إذ سرعان ما انتقل عمل أبيه هذه

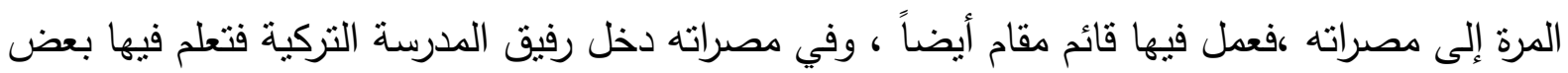

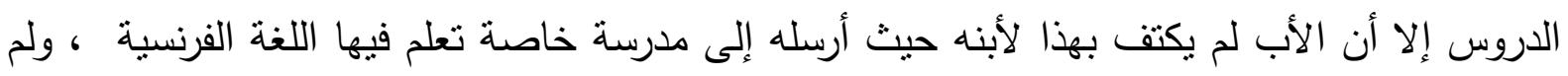

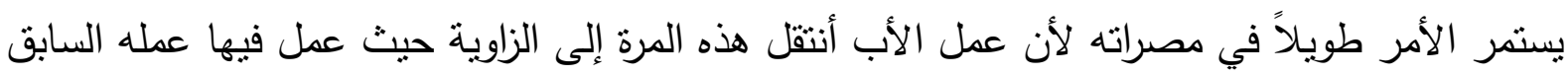
ـ أي قائم مقام للسلطة العثمانية ـ وفي مدينة الزاوية حصل رفيق على الثهادة الابتدائية بالتركية والعربية سبب كون التعليم الرسمي آنذاك كان بالتركية، ارتقى بعدها الثاعر إلى التعليم الإعدادي الرسمي وكان عندها في الثالثة عشرة من عمره .

ولم يكد احمد رفيق يباشر أول يوم له في التعليم الإعدادي حتى دوت مسامعه أصوات الانفجارات

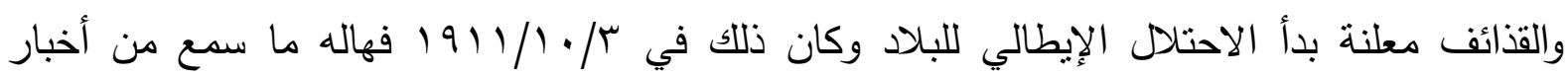
المجازر البشعة التي أحدثها الغزاة كمزرة المنشية التي أبيحت فيها البلدة لعدو مخمور متغطرس حتى 
لم يكد أن ينجو فيها شيخ أو طفل أو امرأة ، فامتلأ قلبه حقداً وغضباً ، كما امتلأ نشوة وحماساً وفخراً

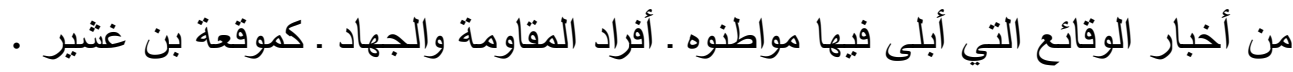
كانت الزاوية في هذا الوقت كغيرها من المدن الليبية مركزا قيادياً للمقاومة والجهاد ، يتجمع فيها المقاتلون والمجاهدون وفيها ينوجهون إلى ميادين التتال تماما كما كانت مسقط رأسه ـ مدينة فساطو . وكما كان ابن بلدته الثيخ سليمان الباروني كان أبوه (قائم مقام المدينة) فقد كان يشرف شخصياً وبمساعدة رجل عربي غيور يدعي فرحات بك على تجنيد المجاهدين وإرسالهم إلى منطقة الجهاد ،

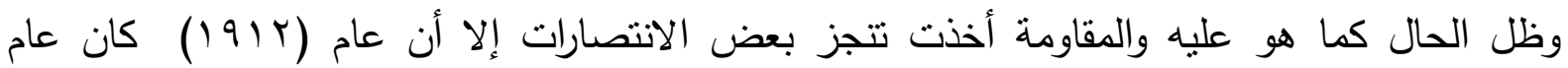
الخذلان للمقاومة ، وذلك بسبب المعاهدة التي أبرمتها الدولة العثمانية مع الإيطاليين في البلقان ، اذ اذ الذان أصبح من المحتم عليها التخلي عن مساندة المقاومة ، ومن ثم كسر شوكتها واستسلام البلاد نهائياً للمستعمر ، وعلى أثر ذلك أصيبت الجماهير بالصدمة ، وكرد فعل على ذلك اتجهت بعض الأسر إلى لى الهجرة للبلاد العربية المجاورة ، ولا سيما مصر التي استقبلت عائلات لييية كثيرة منها عائلة الثاعر التي استقرت في الإسكندرية عام (r (9 (1) مع عائلات لييية كثيرة منها على سبيل المثال عائلة الثاعر أحمد الفقيه حسن ،وهكذا وجد رفيق نفسه في حياة جديدة غير التي عرفها من قبل في فساطو ومصراته والزاوية ، حياة امتدت نحو ثمان سنوات ـ أب منذ كان في الخامسة عشرة حتى بلغ الثالثة والعشرين من العمر. وهي مرحلة كما هو معروف من أخطر المراحل العمرية التي يمر بها الإنسان ،لأنها مرحلة

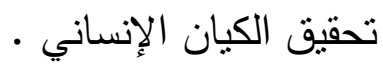
لقد وجد رفيق نفسه في الإسكندرية يتلمس مقومات شخصية بالاعتماد على نفسه ، ولا سيما بعد أن فقد والدته عام (1911) فرخل في مدارسها الحكومية تارة والمدارس الدينية الخاصة تارة أخرى ، فأكمل تعليمه الأكاديمي الابتدائي بإحدى مدارس رأس التين ليتمكن بعد ذلك من الانتظام في سلك التعليم الثانوي ، فاتجه إلى المعهد الديني بعد أن أخفق في الالتحاق بمدرسة الجمعية الخيرية الإسلامية وهناك 
بقي سنتين تعلم فيهما شيئًا من البلاغة العربية والتعبير والحديث، ولكنه كان ينأى بنفسه أن يكون رجل دين، لذلك نراه يتحين الفرصة للانضمام إلى المدارس المدنية غير الدينية ، وما كادت هذه الفرصة تتاح له حتى استغلها وبادر إليها فالتحق بمدرسة الجمعية الخيرية الإسلامية وظل فيها إلى أن قارب حصوله منها على شهادة البكالوريا لولا قرار العائلة بالرجوع إلى بنغازي عام (• ب ( ) ) .

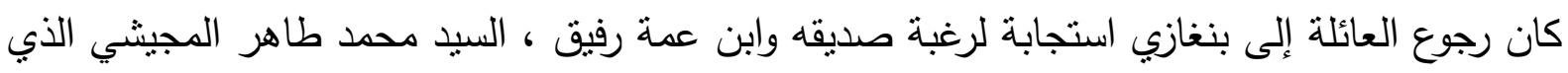

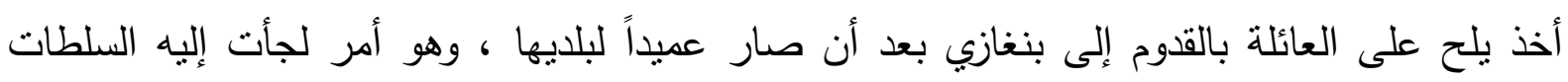

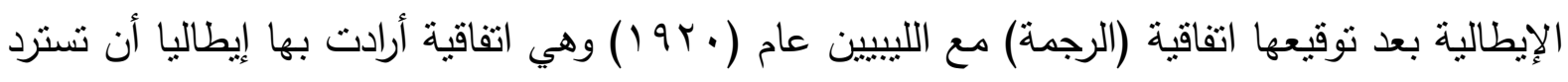

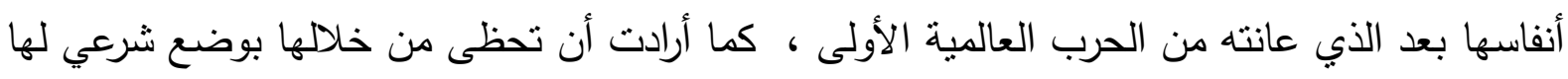

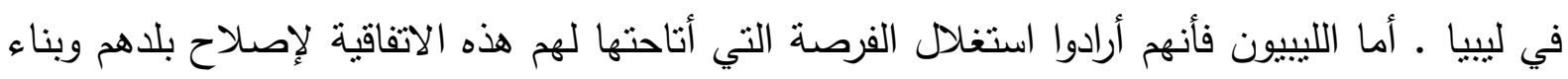
مؤسساته المدنية وكان أن أتبعت السلطات الإيطالية سياسة المهادنة مع الليبيين بغية كسب ودهم وخداعهم في

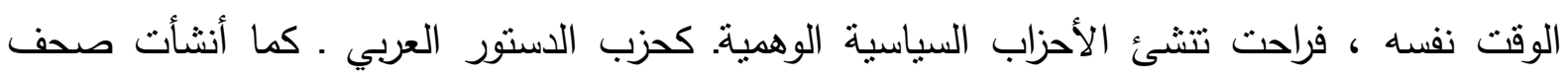

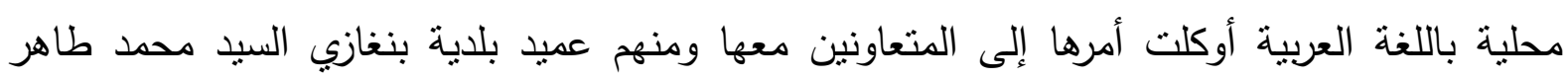

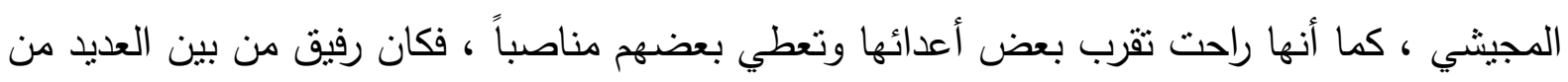
المواطنين الليبيين الذين استثرجتهم السلطات ليحققوا لها ما عجزت عن تحقيقه بالسيف فكانت تتودد إلى هؤلاء وتتجمل عليهم بغية تتفيذهم مخططاتها الثبطانية ، فعددت إلى نوظيف رفيق سكرتيراً عربياً في بلدية بنغازي ، إلا أن الثاعر أحس بالخزي والعار وهو يؤيد سياسة التفاهم هذه فراح ضميره يؤنبه وبات

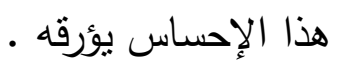

ولكن ما إن جاء عام بrar حتى وجد الاحتقان منفذاً له ، فمن المعلوم أن في هذا العام استردت تركيا مدينة (أزمير) من اليونان بعد أن قطعها الحلفاء منها وأعطوها لليونانيين كنتيجة من نتائج 
الحرب العالمية الأولى ، وكان الحلفاء بعمهم هذا يريدون الإساءة للإسلام، فراح رفيق يشيد بهذا

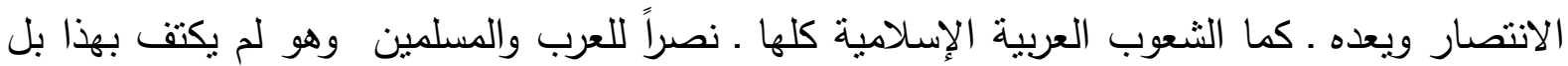
راح يحث الجماهير على مجابهة الاستعمار من خلال فضح أساليبه القذرة بوساطة ما كان ينشره من قصائد ومقالات في صحيفة (بريد برقة) التي أنشأها وأوكل أمرها إلى محمد طاهر المجيشي ومنذ ذلك الوقت صار رفيق هدفاً للإيطاليين بعد أن صار شعره لسان حال الوطنية الليبية في مواجهة الاستعمار

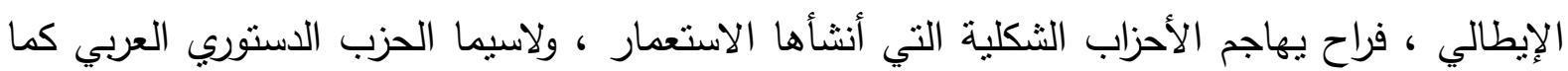
هاجم عملاءه في البلد من بعض رجال الدين الذين ارتموا في أحضان المستعمر ومن بعض ضعاف

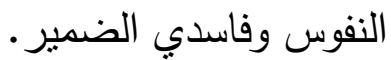
ولم يستمر الوقت طويلاً إذ سرعان ما رجع الاستعمار إلى سياسته القديمة ـ سياسة القمع ـ التي كانت سائدة ، فكان من نتائجها أن عزل الثاعر من وظيفته ، مورست عليه المضايقات فقرر الالتحاق بأبيه الذي كان قد أستقر في تركيا منذ الهجرة الأولى، فكان له ذلك في عام (1901 ). وفي نركيا (بلد الرجل المريض) أحس رفيق بالغربة والضياع والخزي ، لأنه نرك وطنه وحيداً نهباً للمستعمر ومن هناك ـ من بلد الرجل المريض ـ راح يرنو ببصره نحو ليبيا ويقول( () : تركت موطن آبائي على مضض لما تجرعت من هم وويلات

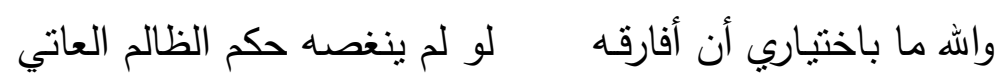
اني لأذكر يوم البين إذ هملت مدامعي فوق خدي مستهلات

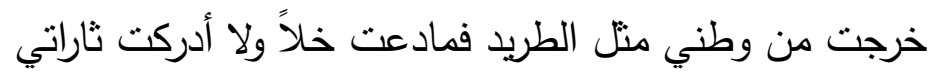
وكان رفيق لا يحب الأتراك والإقامة في بلادهم ، لأنه كان يرى فيهم أناساً لا يوافقون مزاجه الأمر الذي ضاعف عليه المحنة ، فقال بعد مرور عام له في بلادهم (r):

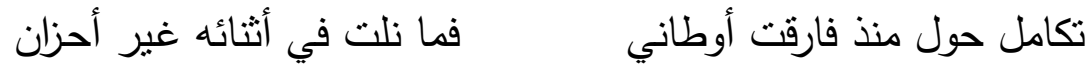




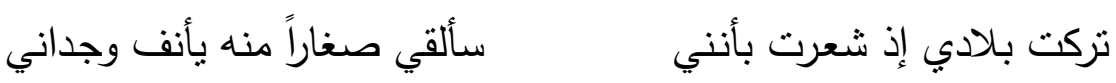

$$
\begin{aligned}
& \text { فيا خيبة المسعى إلى غير موئل من النجع مشفوع بأعظم خسران }
\end{aligned}
$$

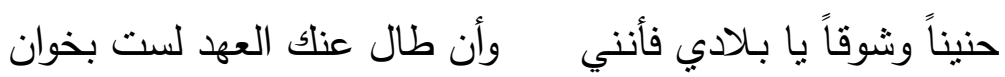

ونتيجة لشعوره بالغربة في بلاد الرجل المريض وعدم تمكنه من التأقلم معها قرر العودة إلى بنغازي ،

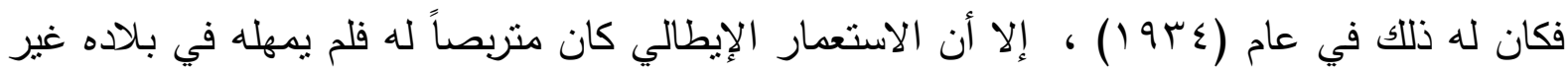
سنتين أكتحل نظره به ، فطرده هذه المرة من البلاد مكرهاً عام (דب9 () فرجع قافلاً إلى نركيا ثانية

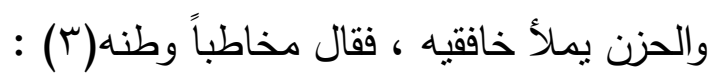

$$
\text { وديلي عنلك عز علي جداً }
$$

وهناك في تركيا راح يتتقل في وظائف حكومية عديدة من الجمارك إلى دائرة استملاك الأراضي فأنغدس في شؤون الحياة ، إلا أنه لم ينس وطنه فقرر الرجوع إليه طالما سنحت له الفرصة في ذللك ، وذلك عندما اندحرت قوات المحور على يد قوات الحلفاء فتخلصت ليبيا من الإيطاليين فكان لها الاستقلال

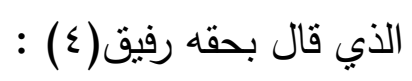

$$
\text { فازت قضيتنا بكل نجاح فاليوم يوم السعد والأفراح }
$$

وفي هذه المدة ، أي بعد رجوعه من تركيا إلى بلده، لم يقبل أي عمل على الرغم من الضائقة التي كان

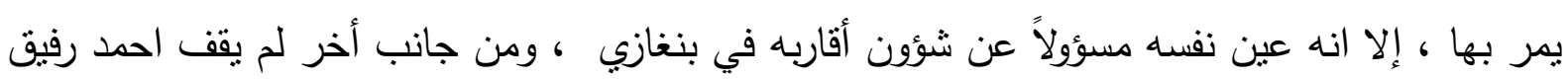
في شعره عند حد الاستقلال ، فبعد الاستقلال هناك الظواهر السلبية التي راح ينتقدا في شعره ، فراح يدافع عن المساجين الذين سجنوا لأنهم رفعوا أصواتهم منددين بما يجري في وطنهم من امتهان للكرامة وإهدار للحريات ، وبعبارة أخرى راح رفيق يسخر قلمه وشعره في خدمة قضية بلاده وتوجيه أبناء وطنه إلى ما فيه خير الوطن وعزته وكرامته ووحدته واستقلاله وتقدمه وإصلاح أحواله ، وفي محاربة 
الانحرافات السياسية والاجتماعية التي حدثت في المجتمع ، وظل هكذا حتى يوم / / / 197/ وهو اليوم الذي وقف فيه هذا الليل الغريد عن الإنثاد في سبيل الاستقلال ووحدة البلاد ومقاومة الظلم والانحراف والطغيان والاستبداد والإصلاح السياسي والاجتماعي لترفع روحه إلى البارئ عز وجل (0).

تألفت بعد وفاته لجنة من الأدباء وذوي الاختصاص أطلق عليها (لجنة الرفيقيات) كانت مهنها جمع أشعار الثاعر ونشرها لأن الثاعر كان قد رفض كل المحاولات في أثناء حياته لطبع ديوانه فعملت اللجنة على جمع أشعاره وتقسميها على ثلاثة أقسام :

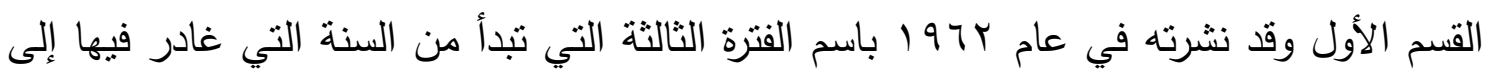
تركيا حيث يقيم بعض أفراد أسرته ـ أب في عام (9 (9 ) ـ وانتهت في السنة التي عاد فيها إلى ليبيا بعد

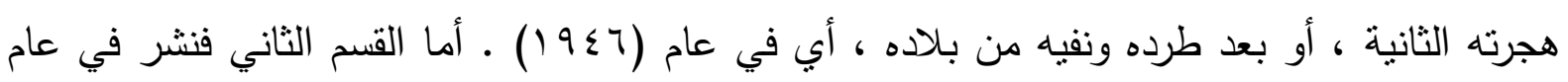

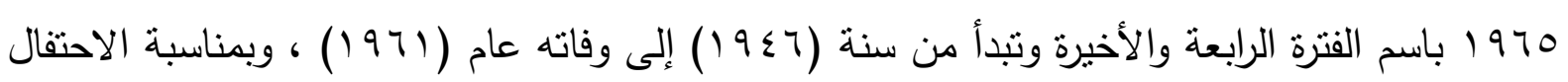

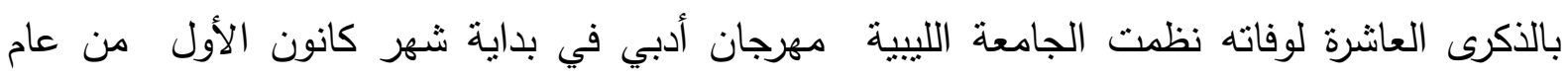

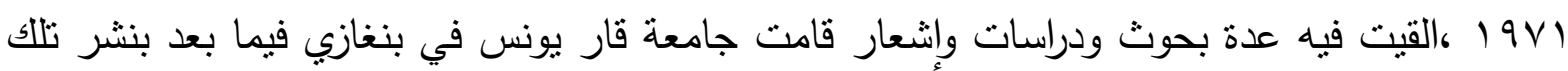

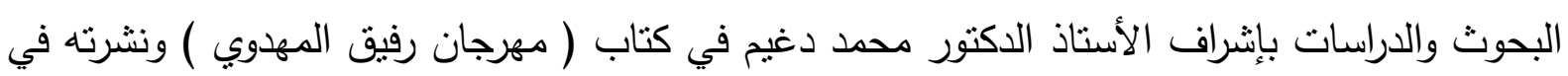
عام( ب991) ، وقد استغلت اللجنة المشار إليها فجمعت ما عثرت عليه من شعر مبكر للثاعر سبق

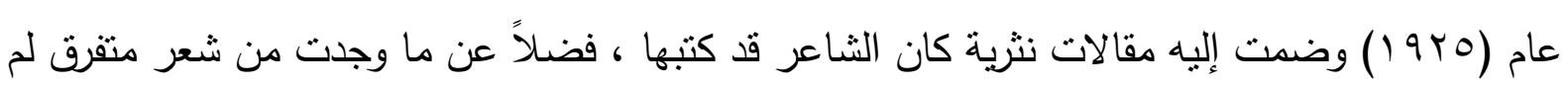

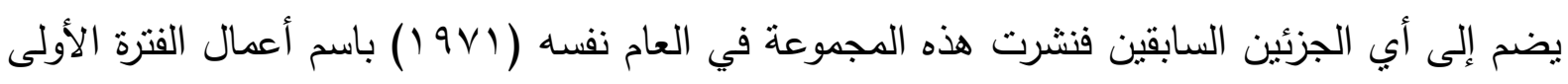

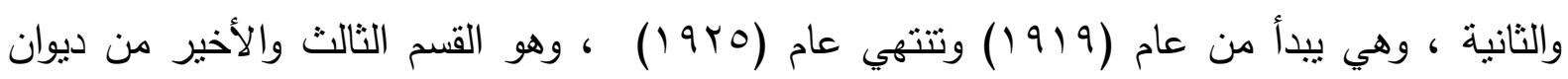
الثناعر - 
أحتل الثعر الوطني الحيز الأكبر في شعره حتى اطلق النقاد عليه لقب (ثاعر الوطن الكبير)(7) ،الذي أستحقه عن جداره ومما تجدر الإشارة إليه هنا ، هو إن الثاعر لم يكتف بالعربية الفصحى للحديث عن وطنه وهمومه بل راح ينظم بالعامية في الغرض ذاته أسمعه يقول (V):

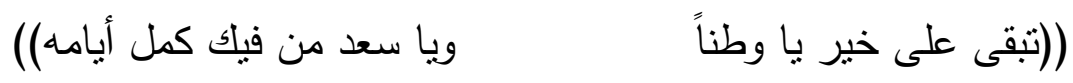

\section{مكانته الشعرية :}

على الرغم مما يبدو ـ للوهلة الأولى ـ من ضعف الصلة بين الأدبين ـ الليبي والأدب العربي . عموماً ، ولاسيما الذي ظهر في أواخر القرن التاسع عثر وفي بداية القرن العشرين ، إلا أن الباحث

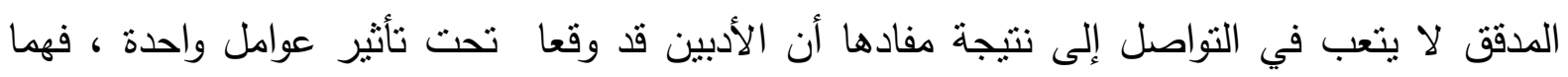
يعيثان في واقع حضاري وبيئة ثقافية وظروف اجتماعية وسياسية تكاد تكون واحدة ولذلك فليس من المستغرب أن نجد في الأدب الليبي صدى للحركات والمذاهب الأدبية التي ظهرت في بقية أقطار الوطن

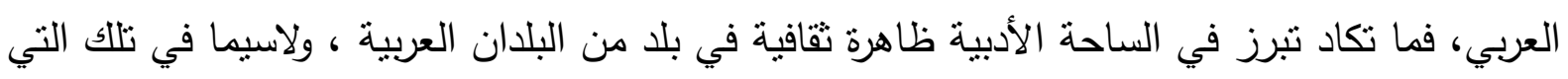

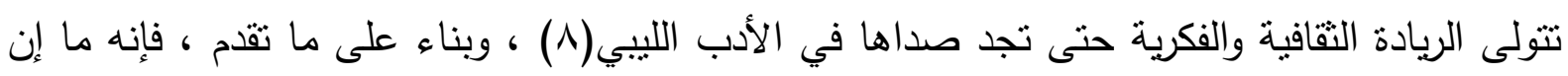

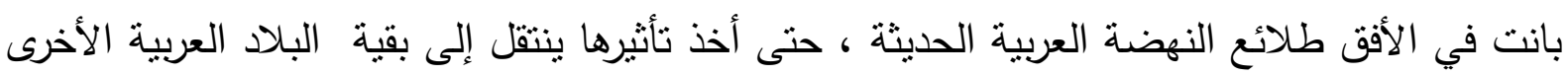

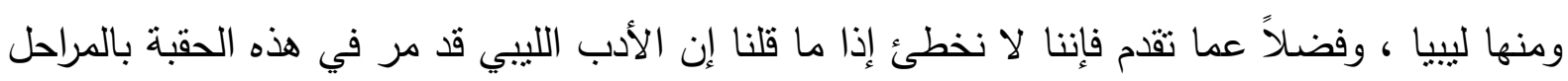
والأطوار نفسها التي مر بها الأدب العربي في البلدان العربية الأخرى، فوجدت فيه اتجاهات أدبية وشعرية مماتلة لما وجد في بلدان الريادة الثقافية والفكرية العربية كمصر والعراق وسوريا ،التي برزت فيها المدرسة الإحيائية ، التي تدعو إلى تعميق الصلة بالثراث الثعري القديم وبث روح جديدة فيه سعياً منها إلى إحباء ذلك التراث، لأنها وجدت فيه السلاح النافع لمواجهة التطور الحضاري الذي جلبه المستعمر

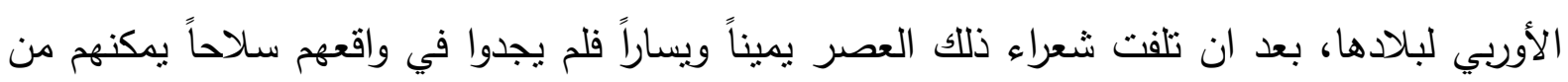


الوقوف أمام ذلك الدد الحضاري الهائل الذي أخفاهم إلى درجة أنهم ظنوا انه كاسحهر ، وذلك لأن كل ما في واقعهم لا يتعدى المرض والجوع والتخلف ، لذلك قرروا الرجوع إلى شيء يفتخرون به يمكنه معادلة الواقع ، فرجعوا إلى تراثهم الثعري الذي كان - حسب ظنهم - القادر الوحيد على معادلة الواقع ، في ظل هذا الواقع عاش أحمد رفيق كما عاش أحمد الثارف ، وبكلمة أخرى فان المهدوي ينتمي إلى بلى برتي المدرسة التقليدية الإحيائية ، بل هو رأسها في ليييا ففي إطارها عاش وعليها تربى وفي رموزها ـ كالزهاوي والرصافي وشوقي وحافظ ـ تأثر ومنهم اخذ فنونه ، ومن ثم فنحن امام شاعر ينتمي إلى المدرسة التقليدية ـ الإحياء . في الثعر بكل حذافيرها ، إذ لو تلمست الأسلوبية ـ بوصفها الباحثة عن مواطن الفرادة في النص الأدبي ـ تلك المواطن في شعر المهدوي لما تعدى الأمر جزالة الألفاظ وفخامتها ، شأنه في هذا شأن معظم الثعراء التقليديين ، وإذا القينا نظرة على المضامين لوجدنا غزلاً مستهلك المعاني

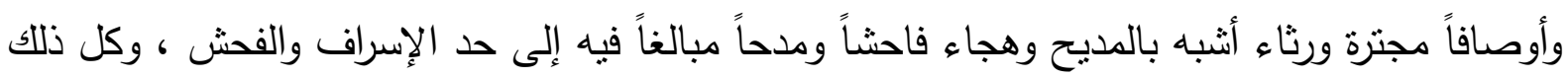
تفرضه المناسبات وكأننا أمام وثائق تاريخية لحياة شاعر أو بلد كما نجد شعراً تعليمياً ووصفاً للمخترعات أعتقد ناظموه أنهم به جددوا في بنية القصيدة العربية ، هذا هو باختصار ما يجمع المهدوي مع الزهاوي والرصافي وحافظ وغيرهم ممن ينتمي إلى هذه المدرسة الثعرية ، إلا أننا هنا لا نبحث في

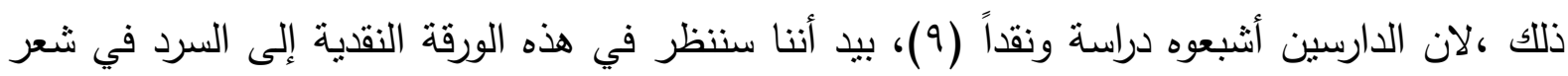
المهدوي بوصفه ابرز شاعر ليبي يمثل مدرسة الإحياء الثتعرية ، وسوف نكون واصفين لا معياريين ننظر في طرائق البناء السردي وما يكتنفه من رموز واشارات ،ولا يعنينا هنا الوقوف على مهيمنات النص الاسلوبية ، ذلك لان دراستتا سردية وليست اسلوبية ، ومن ثم فان دراستتا لا يعنيها كون السرد لا يشكل ظاهرة اسلوبية في شعر احد رفيق المهدوي ، انما يعنينا طرائق البناء السردي للعناصر السردية في

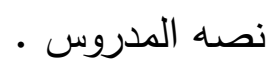




\section{قصيدة الثناعر الكبير احمد رفيق المهدوى \} غيث الصغير \{(· (1) :} هو في الملجأ من دون اليتامى *** دائم الصدت وقارا واحتشاما

واضح الجد قليلا مايُرى *** ضاحكا إلا إذا استحيا ابتساما

يتقي أقرانه صولته *** حين يحتد إذا اشتدوا خصاما

$$
\text { فرموه باحترام هيبة **** وقديما أورث الجد احتراما }
$$

وإذا الجد مع العزم التقى **** جعلا للمرء في الناس مقاما

هو في الملجأ أذكى طالب *** بَّْهم حفظا وفهما وانتظاما

فهو رأس القوم رأياً وهدى**** شيخهم عقلا وان كان غلاما

$$
\text { دون تسع ناحف، في صحة **** واستواء كالرّدينّى قواما }
$$

$$
\text { جئت إعجابا بها اسأله *** فتبسمت وأهديت السلاما }
$$

هب كالثبل نثاطا واقفا *** وقفة الجندي وان كان غلاما 
اطرق الرأس وحيا خافضا **** طرفه منى حيا واحتراما

قلت ياغيث ألا تخبرني *** * عنك أنى بك قد زدت اهتماما

فيك ياغيث توسمت فتى *** أروعا حرا وآباء كراما

ابن من أنت ؟̊ومن قومك ؟من **** للك في ذا الملجأ اختار المقاما

لم أكن احسب أنى باعث **** منه حزنا كان في السر مقاما

كتم العبرة الا نبرة *** عرضت في الصدر عاقته الكلاما

جاشت النفس بحزن متلما *** جالت الدمعة في الجفن انسجاما

وانثتى مبنسما حزنا وما *** أقبح الحزن إذا لاح ابتساما

قال :يامولاى لو غيرك لم *** ابكِ في حضرته أخشى ملاما

منك آنست حنانا لم أجد *** بعد أمي مثله يشفى أُواما 
إن للثاعر روحا خلقت **** فوق روح الخلق حسا وغراما

للك يامولاي أفضي بالذي **** كاد صدري منه ينشق اكتتاما

إن في الثكوى إلى ذي رحمة **** سلوة تنبه بالصبر اعتصاما

رب شكوى جعلت نار الأسى *** نار إبراهيم بردا وسلاما

فارعي لي سمعا فهذى قصني *** تشرح البؤس ابتداء وختاما

كان مسعود أبى في قومه **** سيد الأعراب معروفا هماما

فارس الخيل غياث الدتمى *** مكرم الضيف كفيلا للأيامى

بارك اله له في ثروة *** * تملأ الوادي ثخاء وبغاما

وله من بنت عم اخوتى **** خمسة تتنقص البدر التماما

مرت الأيام لم نعرف لها *** كدرا من نعم كانت جساما 
فكان الدهر إذ سالمنا **** سهر السعد لنا والنحس ناما

ثم لما غلبت شيمته **** قعد السعد وهول الخطب قاما

بينما الحي رقودا إذ علت**** صرخة تتذر بالثر النياما

ثارت الأطفال من مضجعها **** تملأ الرحب صباحا وزحاما

رجت الأرض صهيلا مفزعا **** ورغاء ونباحا وخصاما

لبسوا ثوب الدجى ايدى سبا **** يخبطون البيد في البر انهزاما

تركوا الأثقال والمال وما *** خف حملا والمطايا والخياما

ورأى الأبطال إن الموت لا *** شك فيه فتلقوه زؤاما

قبدوا أرجلهم صبرا فما *** حلها غير رصاص يترامى

حلها من ربقة العار ومن *** عيشة الذل فقد ماتوا كراما 
هون الخطب علينا موتهم *** في دفاعا كان للحق انتقاما

ماترى في الحي حيا بعدما *** فرت النسوة يحملن اليتامى

سلكوا في كل شهب هربا * ** يستجيرون من الظلم الظلاما

لست أنسى إخوتي في جبل **** بتضاعون من الجوع صياما

منذ يومين يسيرون وما **** شربوا ماء ولا ذاقوا طعاما

ساقنا الخوف إلى غار بدا *** تتوقى الجن فيه ان تتاما

ما دخلنا الغار حتى هجمت **** ضبعة فافترست منا غلاما

وانثت في اثز ثانٍ فاقتفت *** طفلة في لحظة صارت عظاما

وتردى ثالث في هوة *** لم يزد عن قول ( يا أم ) كلاما

أمه تجرى ولا تدرى وفي **** صدرها من لم يطق بعد فطاما 
تركت أطفالها صرعى لها *** لفتة كانت إلى القلب زماما

خلفتي وهى لاتعلم هل *** خلفها اتبع أم(فُتشُّ ) زماما

خانني عزمي ورجلاي فلم *** استطع من شدة الهول قياما

فققدت الرشد مغنيا فما **** قمت حتى هزم الضوء الظلاما

وفقدت الأم لا اعلم هل *** أفلتت بالطفل أم ماتا هياما

ليتتي اسمع عن موتتها *** فلقد أبقت لي الهم لزاما

حبذا الموت ولا العيش هنا **** خاضعا في ربقة الأسر مُضاما

وهنا أجهش غيث ناحبا **** إذ رأى دمعي كالغيث رهاما

وارتمى بين ذراعي فما **** رام عن صدري ضما والتزاما

بينما رحت اهدي روعه *** وإذا بالقوم يبدون اهتماما 
قيل: هذا دولة الوالي أتى *** ليرى في ملجأ البر النظاما

خرج الأطفال واصطفوا**** له للتحيات هتافا وسلاما

جال يستعرضهم ممتحنا **** وهو يختار غلاما فغلاما

ماراى فيهم كغيث إذ رأى *** من ذكاء عجبا فاق الأناما

خاطب الطفل مليئا فرآه *** رابط الجأش فصيحا لا كهاما

قال : هذا عبقري فارفعوا *** قدره إني سأعطيه وساما

فتلقاه بشكر مظهرا *** لسرور تحته يخفي احتداما

وحباه بنقود قائلا *** أعطِ من إنفاقها النفس مراما

قال يامولاى: أقصى غايتي *** صرفها بين الإخلاء اقتساما

لا أحب البخل إنّا معشر *** نؤثر الغير ولو بتتا صياما 
هكذا علمنا آباؤنا *** طيب الاخلاق فعلا لا كلاما

إن أخلاق الفتى أن لم تكن عن *** غريز الطبع لم تبق دواما

عرف الوالي لغيث همة **** ورأى جودا لله يحكي الغماما

زاده راعيا وهل ذوي الفضل *** يرعى لذوي الفضل ذماما

قال : خذ ياغيث هذى مائة *** للك لاتسرف وكن فيها قواما

قال : يامولاي سمعا إنني *** سوف أبقيها وان كانت حطاما

لا أرى المال إذا لم اكتسب**** منه ذكرا حسنا إلا حراما

قال : ماتصنع ياغيث بها **** قل لي الحق ولا تخش ملاما

قال غيث وبدا الجد على **** وجهه يشبه ليثا أو قطاما

إن لي ثارا إذا أدركته *** لا أبالى بعد أن ذقت حماما 
لو تحصلت على مال به **** اثترى عدة حرب وحساما أدرك الثارات ممن قتلوا **** والدي أنى أربد الانتقاما

هو منشودي من الدنيا التي **** لي ساءت مستقرا ومقاما

ليس بالتصربح بالحق وان **** جر وبلاً جرأة تكسب ذاما

إن حر النفس لايحجم عن **** أن يقول الحق للصدق التزاما

نظر الوالي إلى غيث ولم *** يظهر الحقد ولا أبدى ملاما

ورأى أتباعه ما غاظهم *** فتعاطوا نظرة كانت كلاما

اضمروا سوءا ولكن لم يروا **** سبيا يوجب منه الانتقاما

لجئوا ظلما وعدوانا إلى *** أفظع الأفعال إذ كانوا لئاما

عادة النذل اغتيال ولذا ***** جعلوا سرا له السم طعاما 
ماجرى في جوفه حتى سرى**** في وتين القلب كالنار اضطراما

خر للموت صريعا يلتوي **** يطلب الماء فيبدون ابتساما

لم يزل ينفث من فيه دما *** اسود من كبد ذابت رماما

يلفظ الأخر من أنفاسه *** وينادي الانتقام الانتقاما

راح مظلوما شهيدا جاعلا *** لفظة التوحيد لله ختاما

القصة فى شعر احمد رفيق المهدوب :

لقد اتاحت الظروف لي الاطلاع على جل نتاج الثاعر المهدوي ، ولاسيما بعد مكوثي في ليبيا قرابة الخمس سنوات امارس مهنة التدريس في جامعاتها ، وقد وجدته لا يميل الى توظيف السرد في شعره الا نادرا ، حتى اننا يمكن ان نعد قصيدة ( غيث الصغير ) هي الانموذج الناضج في هذا الباب ،

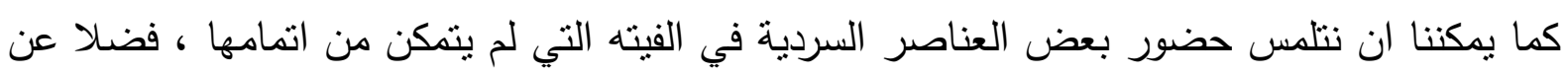
بعض القصائد القليلة الاخرى ، وعلى اية حال فنحن هنا لا نبحث في الاسباب الكامنة وراء هذا الامر ، لان الذي يعنينا هنا هو دراسة طرائق البناء الفني لسرد المهدوي ، وسوف نأخذ هذه القصيدة مثالا عليه ، بوصفها الانموذج الامتل لسرد الثاعر ،وسوف نكثف من خلال عملنا الاجرائي على طرائق بناء 
العناصر السردية ( دلاليا وشكليا ) ،وذلك بعد عزلها الواحد عن الآخر ، منطلقين من مفهوم لا يدعو إلى لى عزل هذه العناصر عن البنية الكلية للسرد ، إنما العزل هنا راجع هنا إلى أسباب فنية غايتها التعرف لهن على طرائق بناء هذه العناصر بصورة واضحة ، فنحن لا نؤمن بما آمن به فلاسفة القرن الثامن عشر الذين اعتقدوا بضرورة فصل الزمان عن المكان (1') ، ولكن نعتقد أن هذه العناصر بمجموعها تؤلف

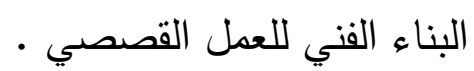
لا نبتعد عن الصواب إذا ما قلنا ان قصيدة " غيث الصغير " هي انموذج من شعر المقاومة ضد المستعمر ، فهي تتحدث عن شاب اسمه غيث (r ( ) يتصف بصفات نؤهله ليكون قائداً ، فقد عائلته يسكن في الملاجئ التي هيأها الاستعمار لسكان الجهة الثرقية من ليبيا ،بعد أن أرغمهم على نرك

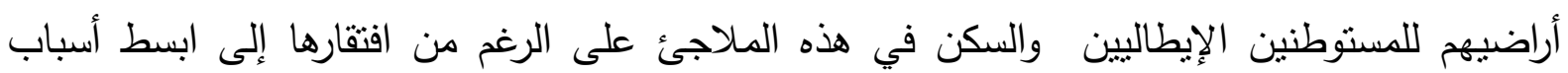

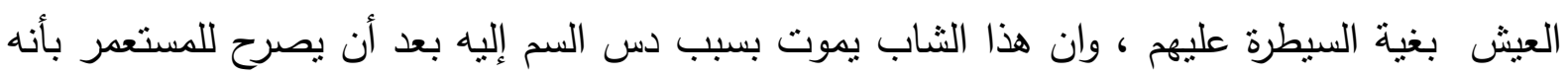
لا يتوانى لحظة واحدة للأخذ بثأره منهم ، هذا هو ملخص المنن الحكائي للعمل السردي الذي بين أيدينا.

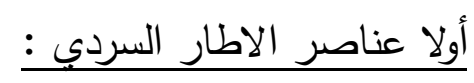

سنبدأ أول الأمر بالوقوف على بنية ما أسميناه بعناصر الإطار السردي في قصيدة " غيث الصغير " ولكننا سنوضح المقصود بهذه العناصر قبل الخوض في ذلك ، فنقول أنها ثلك العناصر السردية التي تؤطر العمل السردي ، التي يمكن تحديد مكان محدد لها على خارطة العمل السردي يكون موقعه في إطار العمل السردي ،فعناصر( العنوان والاستهلال والافتتاحية والخاتمة ) يمكن وضع اليد عليها في النص السردي ، وهي تؤطر العمل السردي ، والثابت في هذه العناصر أنها غالباً ما تكون بنى مكثفة عن بنية العمل السردي برمته ، وبعبارة أخرى فأن بنية العنوان القصصي تساوي أو تعادل بنية

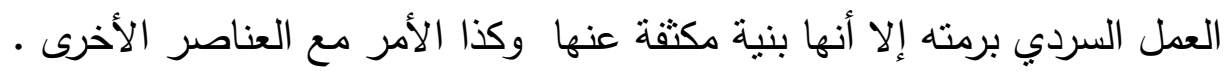


إن عنواناً متل " غيث الصغير " لابد أن يثير في نفوسنا المرجعية الاجتماعية لهذه التسمية ، وذلك

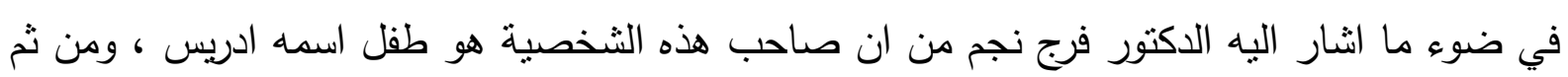
فان خيال الثاعر هو الذي جاء بهذا الاسم ، لنقف قليلا عند دلالات هذا الاسم وعند الاسباب التي من هن هره

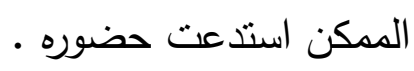

من الثابت ان هناك قبيلة عربية تقطن الثرق الليبي اسمها قبيلة " غيث " ، وهنا تتبادر في الذهن أسئلة عدة ؛ ماذا قصد الثناعر من ذلك ؟ لماذا لم يقل منصور مثلاً ؟ فالمعروف أن الاستعمار الإيطالي طال الغيثي والمنصوري وغيرهما من القبائل العربية على حد سواء ، وهل للثاعر علاقة ما بقبيلة غيث ؟، ام ان ادريس الحقيقي ينتمي الى هذه القبيلة ؟ كام ان لقبيلة غيث دوراً في الجهاد ضد المستعمر اكبر من دور غيرها ؟، وهل إن سكان الملاجئ اغلبهم من الغيثين ؟ ، ما دام الحديث كله يدور حول هذه الملاجئ ، وهل انه كان ينتظر الفرج على يد قبيلة غيث ؟ وهل كان لديه ابن اسمه غيث ينتظر

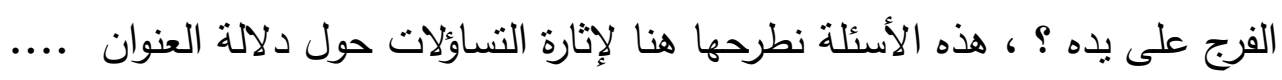
وفضلا عما تقدم فإننا لا يمكننا اغفال دلالة لفظ ( غيث) على الخير الوفير ، فهل قصد الثاعر ذلك ؟ لهاه

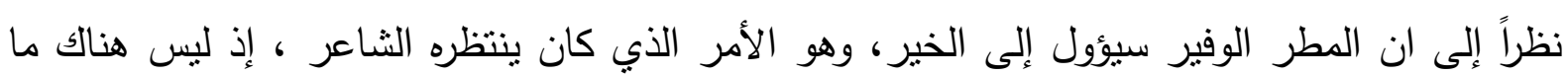

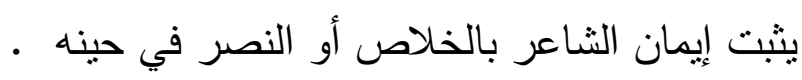

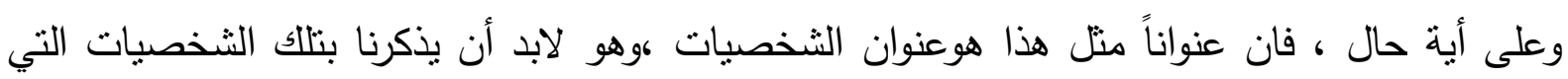
كان الناس يعقدون الأمل عليها كأوديسيوس بطل ( الاوديسة )، ونحن لو طبقنا ترسيمة ( رولان بارت )

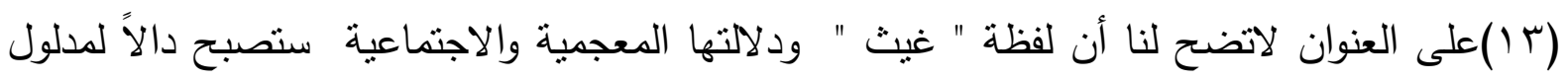
أوسع ،هو انتظار اخضرار الأرض بفعل المطر الوفير الذي يعني في المعنى الإيحائي انتظار النصر

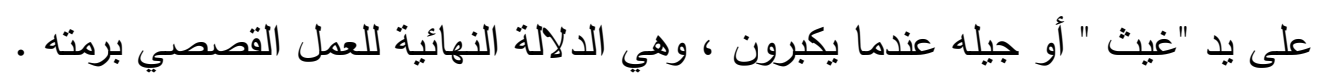




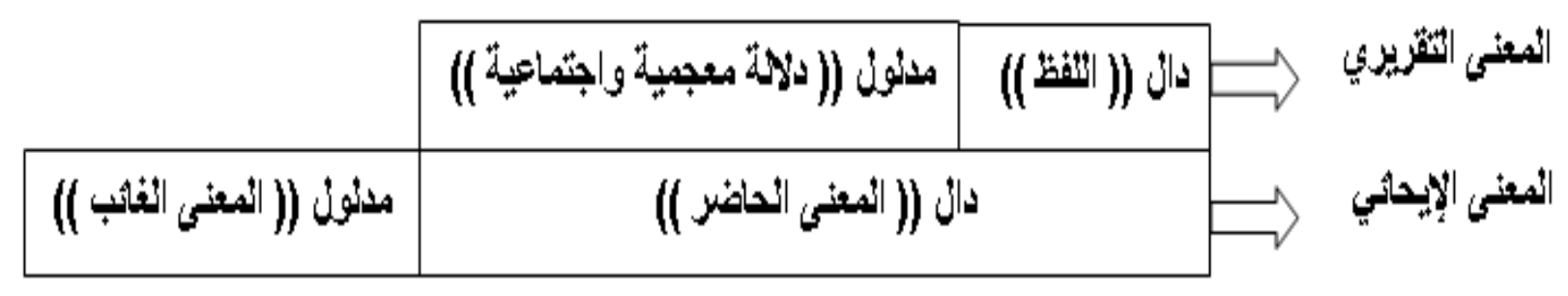

ولننتقل الآن إلى بنية الاستهلال في " غيث الصغير " ، الذي هو بداية العمل الأدبي أو مطلعه ، وهو الذي يولد الانطباع الأول في النفس عن النص ، وهو هنا قول الثناعر:

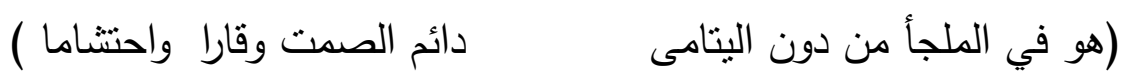
ومما تجب الإثارة إليه هنا ، هو أن الاستهلال السردي غالباً ما يسجل لحظة انتهاء الحدث في الطبيعة

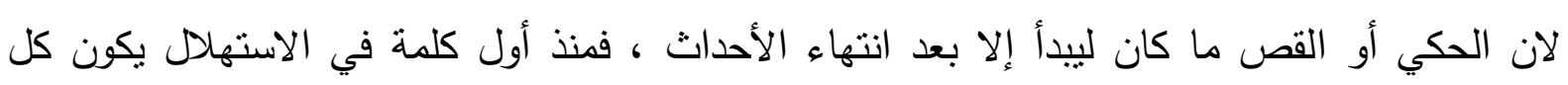
شيء قد انتهى وعلم القاص نهاية حكايته ـ أي ان الراوي يحكي أحداثا انقضت ، وهذا هو سبب ارتباط الاستهلال بالزمن الماضي ، والماضي هنا ليس الماضي الفيزيائي بل ماضي أحداث الحكاية . ونحن لو تتبعنا في هذه العجالة بعض الاستهلالات السردية ، حتى يمكننا القياس عليها لقلنا ان استهلال المقامة العربية بوصفها فناً سردياً هو قول المؤلف : ( قال عيسى ابن هشام ) أو ما شابه ، وان استهلال الحكاية الثعبية غالباً ما يكون من خارج نص الحكاية وهو قول المؤلف : ( كان يا ما كان )

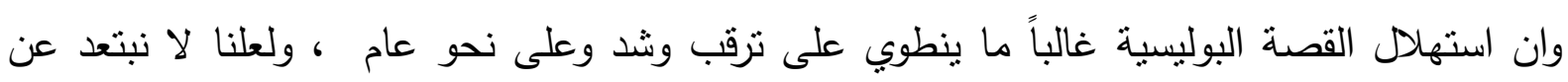
الحقيقة إذا ما قلنا ان اغلب القص القديم شبيه بالدراما من ناحية كون الاستهلال في كليهما يغلب عليه كثف كل شيء منذ البداية ، فهو يغوص في أعماق الأحداث ليمسك بأولها ليبدأ القص منه ، وفي هذا الصدد اقترح جيرار جينيت تقسيم الاستهلال على نوعين أساسيين؛ الاول وهو الذي تكون فيه الثخصية 
الروائية غير معروفة من القارئ أي انها مقدمة من الخارج، ومن ثم يأتي الاستهلال ليعرفها ، وهذا النوع

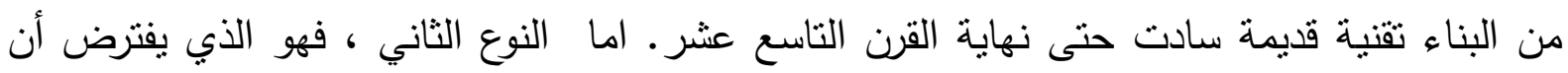
الثخصية السردية معروفة من لان القارئ ـ اما بتقديمها باسمها الأول ، أو بالضمير النائب عنها ، في

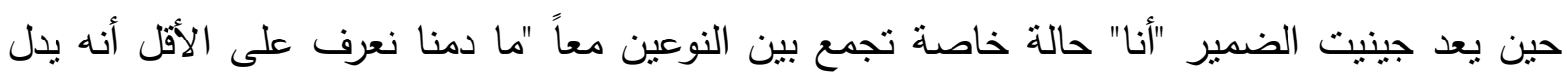

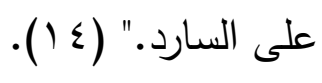

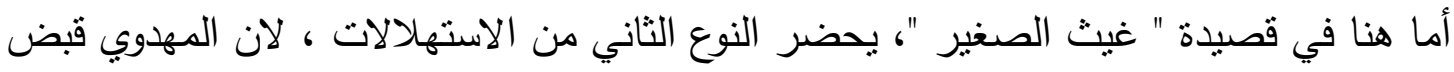

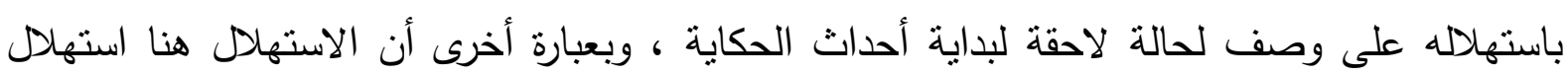
يقتحم الحكاية من دون مقدمات ، بعد ان قدم الثاعر لنا تعريفا ببطله وهو ( غيث الصغير ) بان عنون القصبدة باسمه ،ذلك لأننا لو تتبعنا حكاية " غيث الصغير " لعرفنا ذلك جلياً ، فهو صبي أستشهد ولي أمره ثم أسكنته سلطات الاحتلال قسراً مع أقرانه في الملاجئ ، وفي أحد الأيام شاهده الثاعر بوصفه لئه راوياً عليماً فكانت هذه الحكاية .

بعد ذلك ننتقل إلى الحديث عن بنية الحدث الافتتاحي في " غيث الصغير" الذي هو أول حدث مثمر في العمل السردي ، وغالباً ما يأتي بعد الاستهلال وربما جاء بعد حين ، ولاسيما إذا شغلت بنية

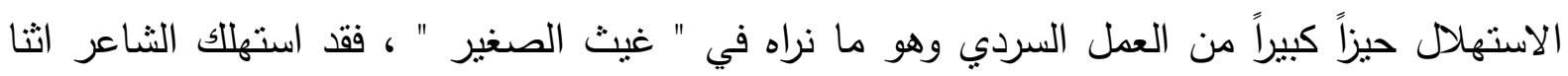

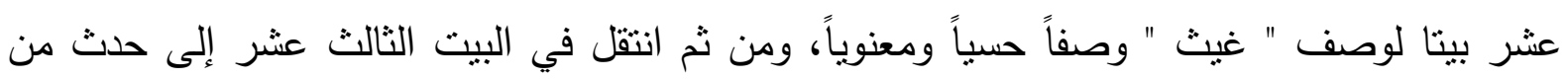
خارج البنية الحكائية فأفتتح به سرده قائلاً :

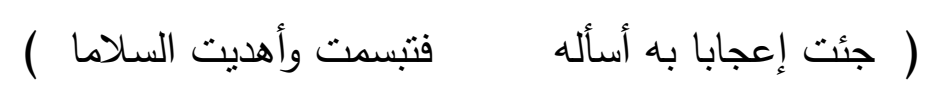

وهكذا يتضح لنا جلياً أن الحدث الافتتاحي هنا مستل من وسط الأحداث ، وهو الأمر الذي تبناه السرد الحديث ، ذلك لان السرد القديم كما السرد التاريخي غالباً ما يلجأ إلى الافتتاح بحدث يسجل أول لهن لهنة 
في الحكاية ، حدث لا يسبقه حدث اقدم منه حتى أن القاص لا يحتاج معه العودة للوراء لتوضيح ما تقدم ، كما نلاحظ أن هذا النوع من الأحداث الافتتاحية غالباً ما يلازم الدراما ، فالحدث الافتتاحي في الدراما يغلب عليه انه يبدأ من نقطة يحتم وجودها عدم وجود شيء آخر يسبقها (10)، ومما لاشك فيه أن أول لحظة في حكاية " غيث الصغير " هي عيش البطل و أسرته عيشة مطمئنة قبل دخول الاستعمار الإيطالي إلى ليبيا وبعبارة أخرى، فان المهدوي قد وظف تقنية لم يألفها السرد القديم بدليل حاجته إلى الرجوع بعد حين للوراء لتوضيح خلفيات هذا الحدث . .

ويصل بنا الحديث الآن إلى آخر عناصر الإطار السردي ، ألا وهو الخاتمة أو النهاية .

فبالاستتاد إلى بعض المعتقدات يعتقد الناس أن نهاية الكون ستكون بظهور الاجال أو البطل المخلص ، أما الطب فأنه يؤمن بأن نهاية الكائن الحي غالباً ما يكون بدايتها ظهور علامات الثيخوخة عليه ، وليس بعيداً من ذلك فأن النقد الأدبي يرى إمكانية التتبؤ بالخاتمة القصصية (T () ، ولان الخاتمة هي خلاصة العمل السردي أو أنها بنية مكثقة عنها شأنها في هذا شأن باقي عناصر الإطار السردي ، لذا أوصى النقاد بضرورة الاهتمام بصياغتها لأنها آخر ما يصحبه القاريء من النص فضلاً عن كونها قفلاً للنص ،هذا إذا كان أوله مفتاحاً له (IV) ، وعلى أية حال ، فقد اتجه النقد في معالجة هذا الموضوع اتجاهين ؛ الأول حاول الاهتمام بدراسة نوعية الخاتمة ، والثاني حاول دراسة إمكانية التتبؤ بهذه الخاتمة بعد الاستتاد إلى التصور الذي يدعو إلى ضرورة إبقاء القارئ أو المتلقي في حالة نرقب دائم وعدم إعطائه الفرصة في التنبؤ بنهاية الحكاية الأمر الذي يثبع غريزة حب الاستطلاع لايه ويجعله مشدوداً للنص (1) ()، ونحن لو استقرأنا في هذه العجالة خواتيم الأعمال السردية المختلفة ،لاتضح لنا أن السرد الحديث غالباً ما يلجأ إلى عدم إثراك المتلقي في صياغة نهاية الحكاية ،كأن بستخدم عنصر المفاجأة في هذه النهايات ،ومن ثم فهو لا يميل إلى النهايات المتوقعة التي يميل إليها السرد القديم ولاسيما النهايات السعيدة، بيد أننا هنا ليس لنا الحق في استبعاد عنصر المصادفة في ذلك(9 ( ) 
وبالاستتاد إلى ما تقدم ، فأن المهدوي سجل موت " غيث " سماً في نهاية قصته ، ليجعل بهذا نهاية قصته نهاية مغلقة على الأقل في الوقت الحاضر ، وبعبارة أخرى فأن المهدوي ما كان بنتظر من بطله

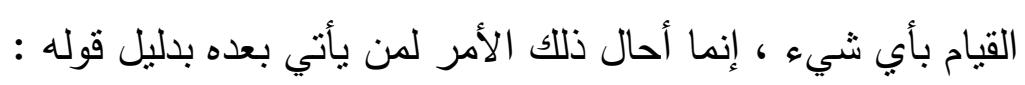
وينادي الانتقاما الانتقاما )

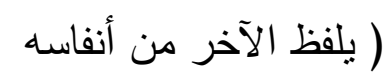

ولما كانت النهايات المفتوحة تصلح لمعالجة المشكلات الاجتماعية كالنفاق والحسد وغيرها ، لان القاص

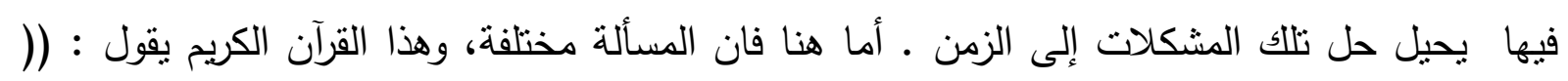

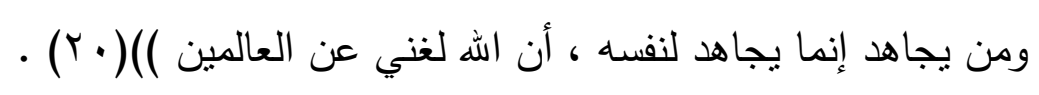
هذا من جانب ، ومن جانب آخر فأننا وبالاستتاد إلى بعض الإثارات التي انطوى عليها النص

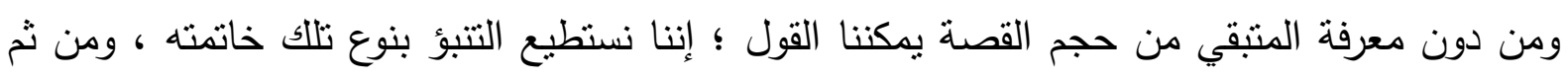
اختفاء عنصر المفاجأة في سرد الحكاية ، فلو قرأنا قول الثاعر على لسان " غيث " بعد أن أعطاه الوالي الإيطالي مائة دينار وسأله أين سينفقا ، فقال : والدي ، أنى أريد الانتقاما ) ( )

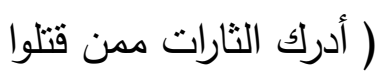
وقوله بلسان الراوي العليم عن اتباع الوالي :

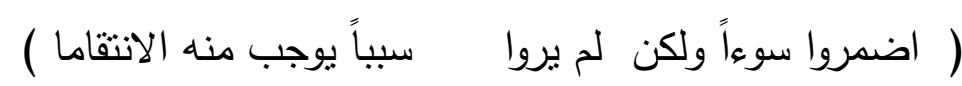
لتأكد لنا ذلك ، وفضلا عما تقدم اجد ان من الضروري القول هنا ان نهاية الحكاية أو المتن الحكائي

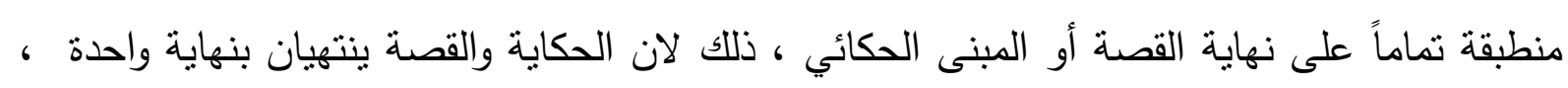

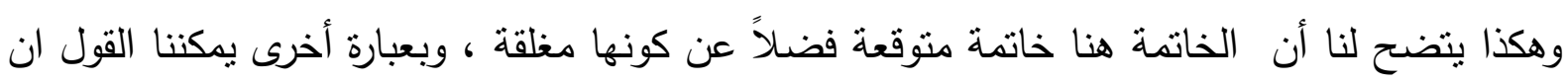
المهدوي كان يتوقع إخفاق محاولات الثعب الليبي للنيل من الاستعمار الإيطالي على مستوى الزمن الذي عاشه الثاعر ، بالاستتاد إلى الفارق الكبير بين الطرفين في العدد والعدة ، ولعل من نافلة القول هنا الاستشهاد بقول شيخ المجاهدين عمر المختار عندما خاطبه الجنرال الإيطالي في أثناء التحقيق معه هن 
قائلاً له : هل كنت تظن انك قادر على طردنا في يوم من الأيام ؟ فأجابه المجاهد الكبير بكل ثقة : لا ، هذا كان مستحيلاً !! وقد علل المجاهد إصراره على الجهاد على الرغم من قناعته بعدم جدواه ؛ بأن دينه يأمره بمحاربة المعتدين بكل ما أوتي من قوة ومن رباط الخيل . وفضلاً عما تقدم ، فأنه وبالاستناد إلى بعض الإشارات يمكننا القول ان المهدوي عندما رسم لنا نهاية الثخصية البطلة بالموت سماً ولم يرسمه بصورة مغايرة ـ كأن نكون الموت شنقاً . ما كان يريد بهذا أن يصور لنا عجز الإيطاليين عن أداء منل هذه المهمة السهلة ، لان لا أحد يصدقه ، فليس هناك ما يخيف المستعدر . على المستوى المادي . من أداء هذه المهمة وقد فعلها مع شيخ المجاهدين ، إنما أراد المهذوي الإثارة إلى أن المستعمر لا يستطيع القضاء على الأجيال كلها ، فإذا كانت صرخة " غيث " بوجه المستعمر تمنل صرخة جيل بأكمله فمن المؤكد انهم لا يستطيعون قتل الجيل كله ، ولكنهم ربما يستطيعون تخديره أو منع وصول هذه الصرخة إليه من الجيل الذي سبقه ، ذلك لان السم هنا وسيلة الجبناء الخائفين ، فضلاً عن كونها وسيلة تخدير وتحذير للجيل الذي يمثله " غيث " ، لان المستعمر لو لم يرد ذلك لقتل الضحية بصورة علنية أمام الناس الأمر الذي سيفسر على انه فتل للجيل بأكمله ، كما فعلوا ذللك مع عمر المختار ، وحتى يؤكد المهدوي هذه الحقيقة قال على لسان " غيث " : ( أدرك الثارات

$$
\text { ممن قتلوا والدي، اني أريد الانتقاما ) }
$$

هذا هو تصور هذه الورقة النقدية للفكرة المركزية للنص ، وبغية تأكيد هذا الأمر فأننا لو طبقنا مفهوم الأسلوبيين والبنيوبين في التعرف على دلالة النص المركزية وقمنا بجدولة دلالات النص المختلفة لاتضح لنا أن النص تحكمه فكرة واحدة يمكننا الكثف عنها من خلا المقارنة بين الثنائية الضدية التي تحكم النص ، إلا وهي ثنائية ( الموت ـ الانتقام ) وما يواز يهما من دلالات ، فمن خلال جمع دلالات الثنائية الضدية نجد أن كفة الموت هي الراجحة أو المهيمنة على كفة الانتقام ، ذلك لان معظم دلالات النص توحي بالموت ؛ فهناك عائلة مشتتة وابن مسموم وأبناء موتى وأب مفقود وأم مجهولة وشعب 
مستعمر يجبر على السكن في الملاجئ وغيرها من الدلالات التي توحي بالموت ، وبالمقابل فأن كفة الانتقام لا تجد سوى تصريح البطل في أكثر من مناسبة في نية الانتقام الذي لا يكفي لرفع كفة هذه الدلالة ، ومن ثم تبقى هذه الكفة هي الخاسرة وتبقى كفة الموت هي المسيطرة الأمر الذي نفسره على انه عدم إيمان الثاعر بعدم حتمية النصر العاجل ، إنما كان يراهن على المستقبل وعلى وصول صرخة الظلم إلى الأجيال القادمة ولتوضيح هذا الأمر نستعين بمربع غريماس الدلالي(Y) الذي يكثف بوضوح ما قصدنا له :

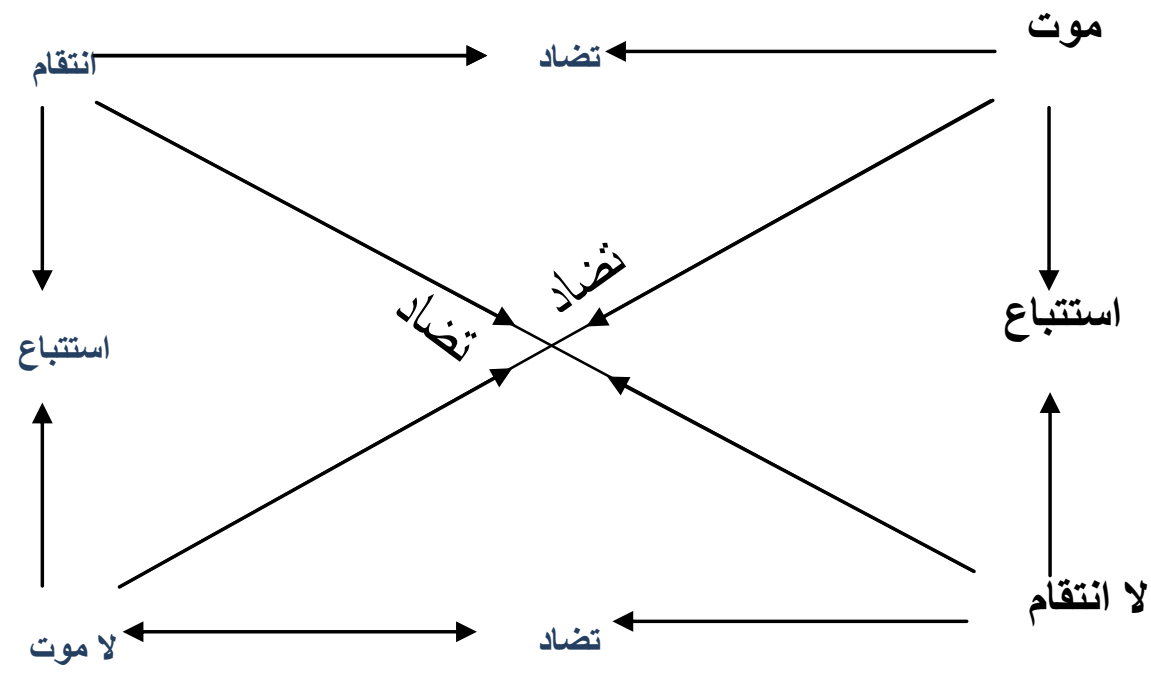

ثانبا : عناصر التكوين السردي :

وهي العناصر الرئيسة في البناء السردي ، التي لولاها لما قام البناء السردي ؛ وهي ( الثخصية . الحدث ـ الزمن . المكان ، ونبدأ بعنصر الثخصية فنقول : أن النقد القصصي حاول النميز بين نوعين من الثخصيات ؛ النامية أو المستديرة وهي شخصية متطورة بتطور الأحداث وغالباً ما تكون صفاتها 
مبعثرة هنا وهناك يلتقطها القارئ ليكون له تصور عنها ، والثخصية الثانية هي الثخصية الثابتة أو المسطحة وهي شخصية سلبية لا حراك فيها معلومة الصفات منذ البدء ، كما حاول النقد التميز بين الثخصية البطلة التي نكون المحور الذي تدور حوله الأحداث والثخصية الثانوية ، كما ميز النقد بين أنواع مختلفة من الثخصيات البطلة ، فهناك على سبيل المثال بطل أسطوري وآخر ملحمي وآخر شعبي

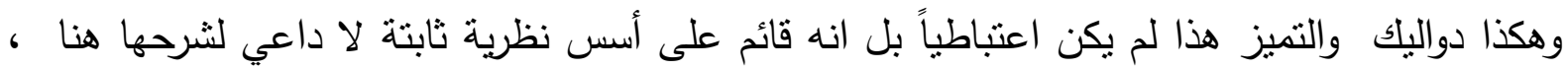
وفضلاً عما تقدم ، فقد كثف النقد القصصي عن طرائق عرض تلك الشخصيات فوجد إنها طريقتان ؛ الأولي الإخبار المباشر وهي طريقة قديمة استهكها السرد القديم ، أما الثانية فهي التي حاول السرد الحديث توظيفها وتتمثل بإظهار صفات الشخصية عبر حواراتها وأفعالها ، ذلك لان القارئ الحديث يفضل اتخاذ قراره بنفسه عن الشخصية ولا يرغب في الاعتماد على تقارير الآخرين ، وأخيراً فقد وجد النقاد أن هناك وظائف للثخصية القصصية غير وظيفة فعل الحدث القصصي وقد حاول بعض النقاد تحديدها(YT)

وبناءً على ما تقدم ، فانه ومن خلال نظرة سريعة على شخصيات " غيث الصغير " يتضح أن شخصية " غيث " هي الثخصية البطلة ونحن نلمس أنها شخصية نامية قد تطورت مع الأحداث حيث هيأها الاستعمار لتكون أداة انتقام ، أي أنها شخصية انتقامية حسب تعبير علماء النفس ، والملاحظ على هذه الثخصية أنها شخصية قربية من الشخصية الواقعية لإنسان اليوم ، فهي تمثل معاناة إنسان اليوم وجهده الدوؤب في التعبير عن ذاته والدفاع عن نفسه أهله ومجتمعه اتجاه قوى الثر المحيطة به ، وبتعبير آخر أنها تمنل البطل الثعبي في مجتمعاتتا ـ

أما طريقة عرض هذه الثخصية في نص المهدوي ، فهي الإخبار ، فكما هو واضح أن المهدوي عدد إلى عرض صفات هذه الشخصية . بشكل رئيس . عبر الاستهلال الذي استغرق اثتي عشر بيتاً ، وقد اخبرنا فيها . بوصفه راوياً عليماً. عن كل ما يتعلق بهذه الثخصية وهو لم يتزك لنا المجال لكثف 
صفاتها بأنفسنا عن طريق سلوكياتها أو حواراتها ، بل قرر هو أنها شخصية انتقامية ولها من الصفات ما لا داعياً لذكره هنا

أما فيما يخص الوظيفة التي تؤديها هذه الثخصية ، فهي فضلاً عن كونها فاعلة للحدث الرئيس في الحكاية كانت ترمز إلى جيل بأكمله ، أي أنها كانت تؤدي وظيفة رمزية ، ومن جهة الثخصيات غير البطلة ـ الثانوية ـ فان أهم تلك الثخصيات هي شخصية الثاعر بوصفه الراوي العليم هنا ، وهو شخصية ثابتة لاحراك فيها لم يشارك في تحريك الأحداث إنما اقتصر وجوده على عرض الحكاية عن طريق حوارها مع البطل ، أي أن وظيفته وظيفة درامية فقط . أما الحدث في " غيث الصغير " الذي هو الوقائع والأفعال التي تقوم بها الثخصية وتكون موجهة نحو نهاية محددة ، فمما لاشك فيه هو حكاية ذلك الفتى الذي اسمه " غيث " الباقي الوحيد من عائلة مكونة من سبعة أفراد شتتها الاستعمار ، فالأب قتل وإلام مجهولة المصير والإخوة ماتوا بفعل الطبيعة التي لا ترحم من يعيش في الكهوف خالي الوفاض من ضروريات الحياة ، ومن ثم بقائه وحيداً في ملجأ أثبه بالسجن ليلاقي حتفه مسموماً . هذا هو باختصار حدث هذا العمل السردي أو متته الحكائي ، ولكن العبرة هنا ليست في الحدث ذاته بل بطريقة عرض هذا الحدث ، اذ نلاحظ أن المهدوي عمد إلى توظيف نسق النتابع في بناء حدثه ، ذلك النسق الذي تنتابع فيه الأحداث تتابعاً منطقياً الواحد تلو الآخر مع وجود رابط بينها ، ولعل من المفيد القول أن هذا النسق البنائي نسق قديم بل هو من أقدمها حضوراً في السرد حتى انه هيمن ولمدة طويلة على السرد بجميع ضروبه ، وهو فضلاً عن كونه بسيطاً وسهلاً هو يقرب القصة من الحكاية حتى يكاد متتها الحكائي ينطبق نماماً على مبناها الحكائي أو ما يسمى بالقصة

أما المكان الذي هو ذلك الفضاء أو المساحة التي تقع فيها الأحداث السردية ، وهو مكاناً متخيلاً يصاغ من الألفاظ مهما كانت درجة تطابقه أو تمانله مع الواقع ، وتأتي أهمية هذا العنصر السردي من 
استحالة بناء الحدث والثخصية في اللامكان، ولعل من الصواب القول هنا ، إن المكان مرتبط بالإدراك

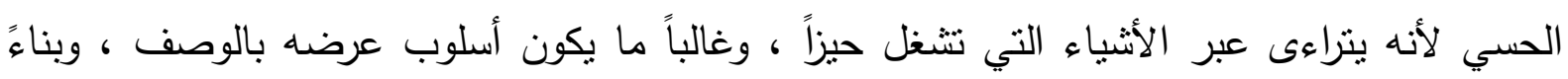
عليه فان دراسة المكان تحتم علينا استخراج المقاطع الوصفية التي يمكن عزلها من جسم العمل السردي ، وذلك لتميزها بنوع من الاستقلالية ولكن هذا لا يعني استحالة اكتثاف المكان عبر الحوار والسرد ، نعم هذا ممكن ولكن الأمر ييقى بحاجة إلى الوصف في تحديد ذللك المكان لأنهما غالبا ما يشيران مجرد الإثارة فقط، ومن جانب أخر لقد كثف النقا الحديث عن العلائق الموجودة بين عنصر المكان ومقصدية المؤلف ، فاستعمال أثنكال معينة من المكان يمكن أن نؤسس عليها تلك المقصدية ، كما

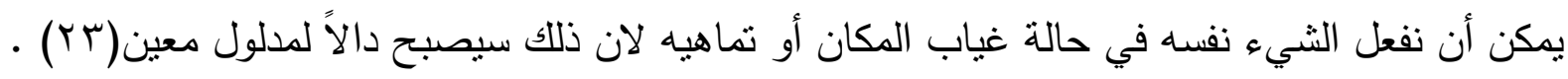

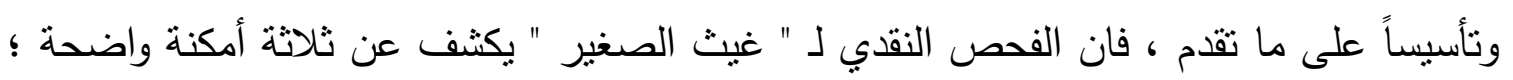

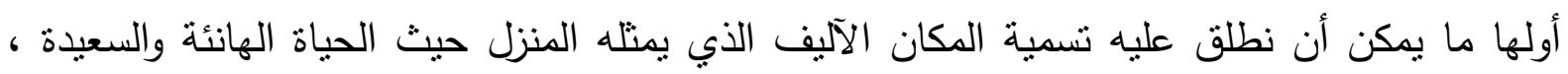
والثاني هو ما يمكن ان نسميه بالمكان المؤقت ،الذي يمتله الكهف الذي استقرت به العائلة بعد الهرب

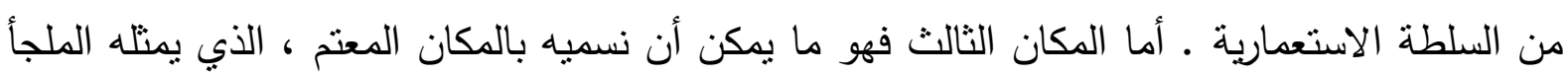

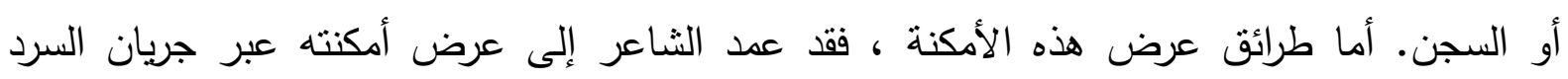

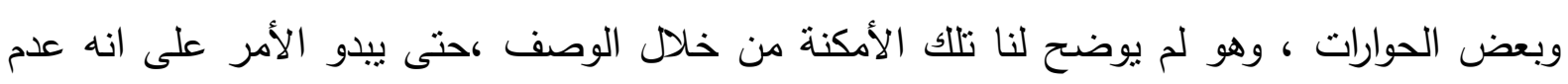

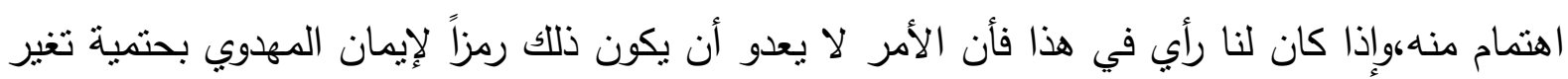
هذه الأمكنة كلها نحو الأحسن في المستقبل. ويصل الحديث بنا الآن إلى آخر عناصر التكوين السردي ألا وهو عنصر الزمن،والزمن هنا ليس الفيزياوي إنما الزمن الوجداني ذللك الذي تقف فيه ساعة الحائط لتدق ساعة القلب ، انه الزمن

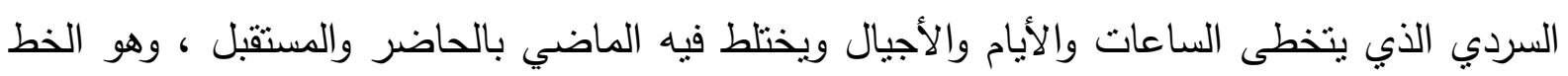
الذي تسير الأحداث عليه ـ ننطلق من هذا المفهوم الذي صاغ على أساسه الثكلانيون الروس قواعدهم 
عندما اعتمدوا الزمن قرينة من القرائن التي أقاموا على أساسها المعارضة بين المتن والمبنى الحكائيين ، ذللك لأن الترتيب الزمني للحكاية أو المنن الحكائي يحيمه المنطق والعقل ، في حين أن الأحداث في المبنى الحكائي تنير على وفق تصور اعتمده القاص يخلق من خلاله الإيهام بحقيقة ما يعرض ، إذ لا منطق زمني هنا فربما جاء أولا حدث زمنه منأخر وبقي الحدث الذي زمنه متقدم في نهاية القصة ئ وعلى أية حال ، فنحن لا نريد الخوض في هذه الإثكالية وسنكتفي بالإشارة إلى أننا سنعتمد على المقارنة بين الزمنيين · زمن المبنى وزمن المتن الحكائين . وسنفصل في الكيفية التي جاء بها زمن المبنى الحكائي لقصة " غيث الصغير " مستندين في هذا على تصورات ( جيرار جنيت )(؟ ب) في هذا

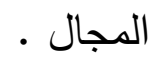

أولا : الترتيب الزمني لأحداث القصة ؛ وهنا نلاحظ أن المهدوي قد بدأ سرده بحدث مستل من وسط الأحداث ولكنه سرعان ما عاد أدراجه إلى الوراء موظفاً ما يسمى بتقنية الاسترجاع ، بيد أن الملاحظ هنا ان الثاعر قد اتبع أسلوباً تقليدياً في استرجاعه عندما جعل " غيث " يروي ما سبق إن حدث بأسلوب المذكرات ، أي انه رجع إلى الوراء ـ وراء الحدث الافتتاحي ـ ليقص علينا ما كان قد جرى على عائلته ، والملاحظة المهمة الأخرى هنا ، هي خلو سرد المهدوي من ما بسمى بتقنية الاستباق ، أي استباق الأحداث واستعجالها وهو الأمر الذي يجعل سرده سرداً تقليدياً لا جدة فيه من هذه الناحية ، ونحن إذ نقول هذا لا يعني إننا نعتقد بإخفاق المهدوي هنا،ذلك لأننا غير معنيين بإطلاق أحكام معيارية • تعلن نجاح أو إخفاق العمل الأدبي

ثانياً : استمرارية الزمن أو ديمومته ؛ وهنا نلاحظ أن المهدوي قد عمد إلى توظيف تقنية المشهد ، إذ أخذت هذه التقنية نصيب الأسد من سرده ، فهو سرد علينا في قصته الأحداث التي جرت على البطل وعائلته بالسرعة نفسها التي جرت عليها في الحكاية أو المنن الحكائي ، أي انه ساوى بين سرعة الزمن في المتن وسرعته في المبنى ، كما عمد المهدوي إلى توظيف تقنية الحذف في سرده ـولو بصورة قليلة . 
ويتضح ذلك جلياً في قوله : ( مرت الأيام لم نعرف لها كدراً ... ) وقوله: ( منذ يومين ...) فالملاحظ

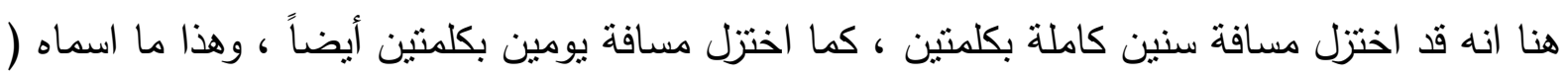

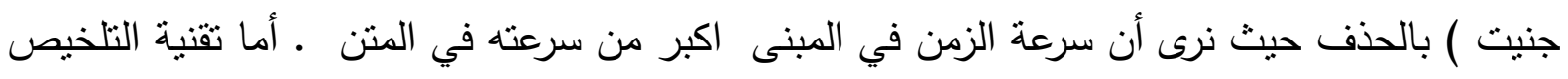
فنتضح جلية عندما يشرح لنا القاص تاريخ عائلة البطل منذ البداية بعدد قليل من الكلمات لا يتتاسب وكبر الزمن المتحدث عنه ، وأخيراً فان المهدوي قد وظف لزمنه هنا تقنيات لا يمكن أن نقول عنها إلا بهات أنها تقنيات نقليدية لا جدة فيها ، ولا يعني هذا بأي حال من الأحوال إننا نحكم بإخفاقه أو نجاحه ، إنما نحن نصف ما نلمسه من طرائق بناء حسب.

\section{ثالثا : عناصر التثكيل السردي :}

نعتقد ان عناصر ( الراوي ـ المروي له ـ السرد ـ المنظور أو وجهة النظر ـ الوصف ـ الحوار ) هي

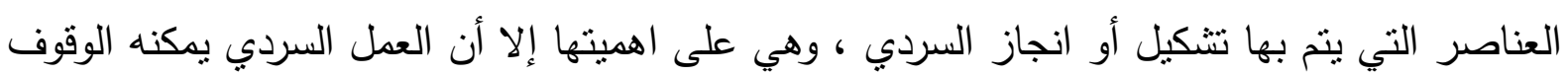
من دونها ، ومن ثم فان صيرورته لا تعتمد على تلاك العناصر ، عكس عناصر البناء السردي ،فالراوي الذي هو الثخص الذي يروي الحكاية ، وهو ليس الكاتب الذي هو من لحم ودم ، إنما هو شخصية

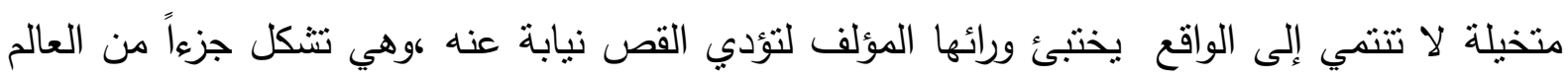

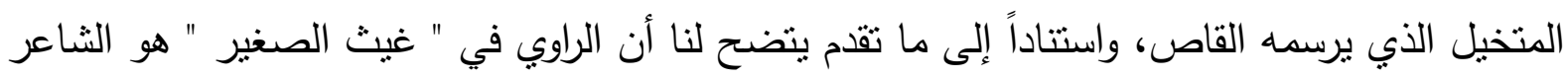
نفسه بوصفه راوياً عليماً غير مشارك بالأحداث ، فهو يلتقط الأحداث من الخارج ويمتلك حرية الانتقال او التتقل بين مختلف عوالم الثخوص القصصية ، وله القدرة على حجب ما يراه ويسمعه عن القارئ ، فضلاً عن امتلاكه حرية التعليق على تصرفات الثخوص وتفسير تصرفاتهم ،وبعبارة أخرى أن الرواية هنا محكومة بصوت واحد وطغيان منظور أيديولوجي واحد أطلق عليه( باختين )تسمية الرواية (المونوفونية )أو( المونولوجية) فنحن نلاحظ احتكار الرواية لشخص واحد ديكتاتوري هو الراوي العليم 


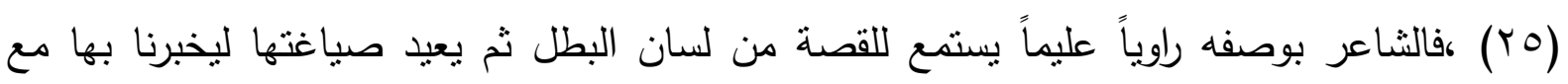

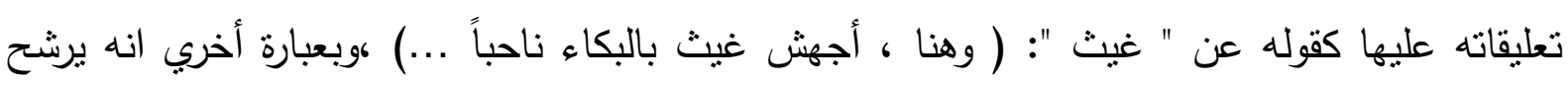
الأحداث عبر لسانه ولا يجعلها تفلت منه إلى شخص آخر ، وفضلاً عما سبق فان الراوي هنا لا يكتفي

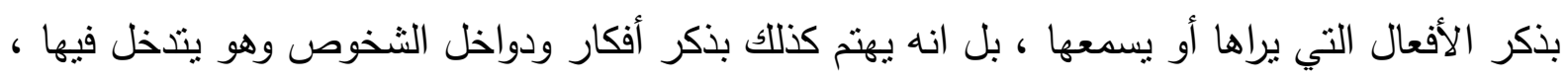

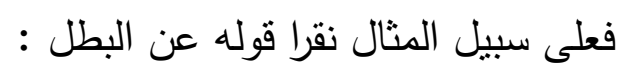

$$
\begin{aligned}
& \text { اضمروا سوءاً ولكن لم بروا سبباً يوجب له الانتقاما }
\end{aligned}
$$

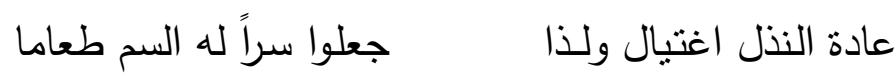

فمن خلا هذين البيتين يتضح أن الراوي لا ينأى بنفسه بعيداً عن الأحداث ، أي انه يسمح لنفسه

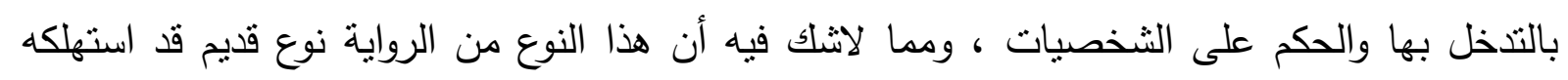

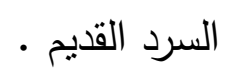

أما عنصر المروي له الذي هو تلك الثخصية المتخيلة التي تقبع في داخل النص والتي تنتمع إلى الراوي وهو يروي حكايته، وهذه الثخصية هي غير شخصية القارئ الذي هو من لحم ودم والذي هو خارج النص ، وربما كانت هذه الثخصية إحدى شخصيات العمل القصصي ، ومن الجدير بالذكر هنا هو انه ربما توفر العمل السردي على أكثر من مروي له واحد كما يمكن أن تكون هناك أنماط مختلفة

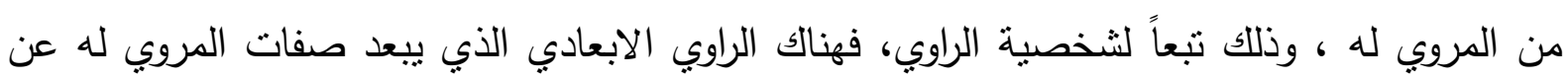

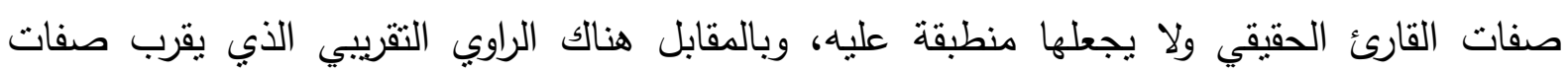
المروي له من صفات قارئ النص الحقيقي، وهناك المروي له بدرجة الصفر الذي لا نجد معه ملامح محدة للمروي له كما في النوعين السابقين ( ب ب). ونحن لو أمعنا النظر في بنية المروي له في " غيث الصغير " لوجدنا ان المهدوي ـ بوصفه راوياً

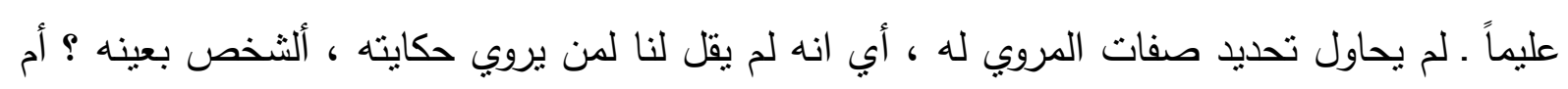


لأشخاص معينين ؟ أو لغير هذا ؟ فهنا لم تحدد صفات المروي له ، وهذا ما أطلق عليه تسمية المروي له في درجة الصفر ، ومما تجدر الإشارة إليه هنا ، هو أن البطل نفسه كان راوية عندما راح يتحدث للثاعر ـ بوصفه مروياً لله . عن إخباره ، وعندها فقط يكون الراوي ابعادياً لأنه ابعد القارئ الحقيقي عن جنس المروي له فقول مثل ( قال يا مولاي ...)لا ينطبق في هذا السياق إلا على المخاطب هنا أو المروي له وهو الثاعر - ماع.

وفيما يخص بنية السرد نقول ؛ إن السرد طريقة للقص أو الحكي يعيد بها السارد بناء المتن الحكائي أو المادة الأولية للقص لينتج نصا سردياً بعد أن بعيد نرتيب أحداثه بطريقة تتوخى الجمال الفني ، أما عن طريق إعادة الترتيب الزمني للأحداث أو بتغير نظامها السببي ونحن لو قلنا مقطعاً سردياً فإننا نعني ذلك المقطع الذي يصف سريان الفعل او الحدث داخل المبنى الحكائي ، ومن الجدير بالذكر هنا ، هو أن مصطلح السرد قد اتسعت دلالته في الدراسات النقدية الحديثة ،بعد إن أصبح السرد يعني الأعمال الأدبية التي طابعها الحكي ، ولكنه هنا بعني عنصرا سرديا ، وان دراسة بنية هذا العنصر السردي تتطلب الوقوف عند علاقته مع الراوي والمكان والزمان ، فمن حيث علاقته بالراوي نجد أن المهدوي قد حاول الجمع بين السردين ـ الذاتي والموضوعي ـ فهو ذاتي عندما قام البطل برواية الأحداث بأسلوب المذكرات بعيداً عن سلطة الراوي الرئيس ـ الذي هو الثاعر ـ وهو موضوعي عندما سرد الراوي العليم . الثاعر . ما اطلع عليه من أحداث ، ومن الجدير بالذكر هنا هو أن الموضوعية التي نعنيها هنا هي عدم الحديث عن النفس والاكتفاء بالحديث عن الغير، وإلا فان الراوي العليم هنا كان يرشح الأحداث عبر ذاته، أي انه يراها برؤيته الخاصة وبريدنا ـ نحن القراء ـ أن نراها بالرؤية نفسها ـ أما من ناحية علاقته بالمكان ، فإننا يمكن أن نطلق على سرد المهدوي تسمية السرد المغلق نظراً لكونه قد ابتدأ من المكان نفسه الذي انتهى عنده ـوهو الملجأ ـوقد فصل بين البداية والنهاية تداعيات وذكريات البطل " غيث "عن أهله ، وأخيراً ، فان علاقة السرد بالزمان قد أفضت إلى طريقة غير تقليدية في البناء السردي 
، وذلك عندما ابتدأ المهدوي بحدث يمكن أن نقول عنه انه يمثل الزمن الحاضر. كما بينا ذلك في بنية الحدث الافتتاحي · ومن ثم استرجاعه أحداث الزمن الماضي عن طريق تداعيات البطل وذكرياته عن تللك الفترة ، وبعد ذلك معاودة الاتصال بالزمن الحاضر عن طريق الراوي العليم ـ وهو الثناعر . الذي بين لنا ما جرى على " غيث " الصغير من أحداث في الملجأ . وننتقل بعد ذلك إلى الحديث عن بنية المنظور أو وجهة النظر ، فنقول ؛ تُعنى الرؤية أو زاوية النظر أو الرؤية أو وجهة النظر أو المنظور، أو غيرها من التسميات التي أطلقها النقاد، عند تودوروف: الكيفية التي يتم بها إدراك القصة من طرف السارد، ولعل من الصحيح القول هنا أن لهذا المفهوم ، أساسه النظري في عديد من حقول الممارسة الفنية، ولربما تتضح دلالته أكثر في الرسم، عندما تختلف هيئات الخيوط والظّّلا، باختلاف زاوية النظر التي ينظر منها الفنان إلى المشهد، الذي تتحدد بدوره أبعاده والمسافات بين مكوناته وفق النظر إليها من هذه الجهة أو تلك، وحسب مدى انفتاح زاوية النظر هذه ، وقد تتضح الصورة في العمل الروائي، إذا حاولنا إسقاط هذا على شخصية الراوي؛ بوصفه المتحكم الأول في تقديم عالم قصه، والواسطة الوحيدة بينه و بين المتلقي ،اذ يُعرف الراوي بأنه : الثخص الذي بروي القصة ، وهو الذي يأخذ على عاتقه سرد الحوادث ووصف الأماكن، وتقديم الثخصيات، ونقل كلامها، والتعبير عن أفكارها ومشاعرها وأحاسيسها ، في حين تُعنى الرؤية بالطريقة التي اعتبر بها الراوي الأحداث عند تقديمها ، فتتجسد من خلال منظور الراوي لمادة القصة، فهي تخضع لإرادته ولموقفه الفكري، وهو يحدد بوساطتها ؛ أي بميزاتها الخاصة التي تحدد طبيعة الراوي الذي يقف خلفها(YV) ، وهنا علينا التتبيه إلى مسألة مهمة هي انه لا يجوز قصر مفهوم المنظور على انه مصطلح فكري أو إيديولوجي حسب ، انه هنا يتسع ليكون زاوية للنظر فضلاً عن كونه منظوراً نفسياً ،على أن ذلك كله يستتد إلى العمل الأدبي كله بوصفه بنية مغلقة ولا يجوز أن نسنده إلى الراوي أو إلى أي شخصية أخرى من الثخصيات القصصية من دون غيرها ، ومن هنا حاول النقاد استعمال 
المصطلحات المرادفة لمصطلح المنظور لكي يبعدوا عن الأذهان خصوصية الإسناد إلى فرد معين

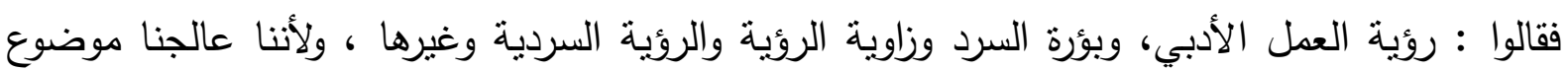
المنظور على المستويين الإيديولوجي والبصري في مبحث الراوي كما عالجناه على المستوبين الزماني والمكاني في مبحثي الزمان والمكان ، فلم ييق علينا إلا أن التعرف على بنيته على المستويين البصري والنفسي ، فنقول ؛ إن الروئة في " غيث الصغير " كانت روئة ذاتية داخلية قد رأت الأحداث من داخلها ، ف" غيث " الصغير والثاعر . بوصفها راويين . تعاملا مع الأحداث من وجهة نظر ذاتية ، لان البلد

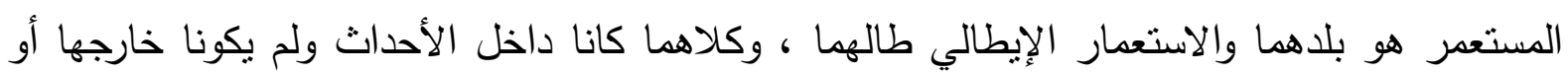
خلفها ، وبناء عليه فان السرد هنا لابد أن يكون ذاتياً داخلياً . بنية الوصف :الوصف هو ذلك الأسلوب الإنثائي الذي يتتاول ذكر الأثنياء في مظهرها الحسي

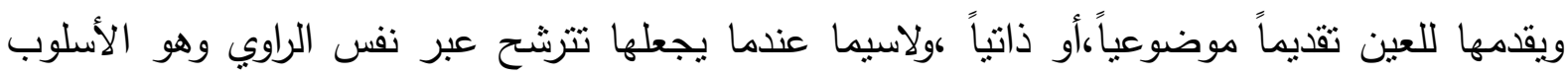

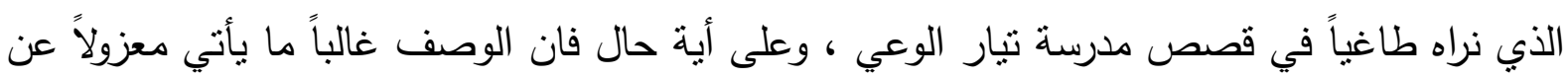
السرد عكس السرد الذي يتشابك مع الزمن . حتى اننا نسنطيع عزل الوصف عن جسم القصة ، إلا في ما يسمى بالمنلوج الداخلي ، عندما ابتكر المؤلفون تقنية حديثة مكنتهم من إدخال الحركة على سلى الوصف ،حتى انه يصعب علينا عزله عن السرد ،الأمر الذي جعل النقاد يطلقون عليه تسمية الوصف

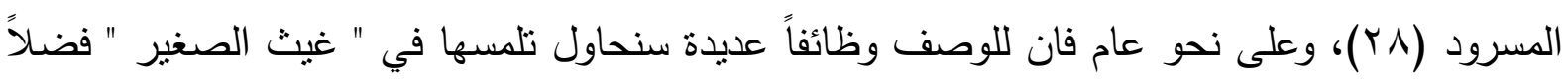
عن الكثف عن طبيعة الوصف في هذا العمل السردي . يبدو لنا أن المهذوي قد استغل الوظيفة التزينية للوصف عندما وصف لنا ـ في استهلاله . شخصية

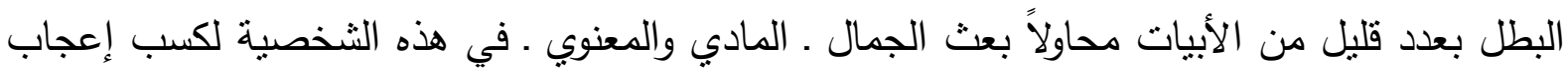
القارئ بها ، وفضلاً عما تقدم فانه يمكننا القول أن المهدوي حاول أن يجعل من وصفه هذا رمزاً تحمله هذه الثخصية أينما حلت ، ولعلنا لا نخطئ إذا ما قلنا انه القيادة ، أي صفات قائد هذه الأمة ، وقد بينا 
هذا الأمر عند حديثنا عن بنية الاستهال، ومن جانب أخر أن المهدوي رصد صفات شخصية البطل الإيجابية رصداً موضوعياً ولم يحاول أن يجعلها تترشح عبر إحساسه ـ بوصفه راوياً عليماً . بل قال معتمداً على حواسه: انه صبي ذكي ونشيط وسريع البديهة وغيرها من الصفات الإيجابية . بنية الحوار:الحوار هو حديث الثخصيات القصصية مع بعضها ، وهو ما اسماه النقاد بالحوار

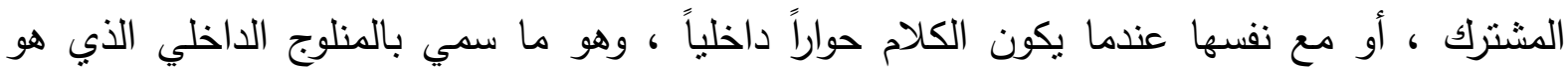
أسلوب حديث في البناء الفني القصصي (Y9)، لعل المهدوي لم يألفه من قبل الأمر الذي جعله يبتعد عنه ، ولكن بالمقابل عني المهدوي بالحوار الشترك الذي دار بين الثخصيات الثانوية والبطل ، ونحن

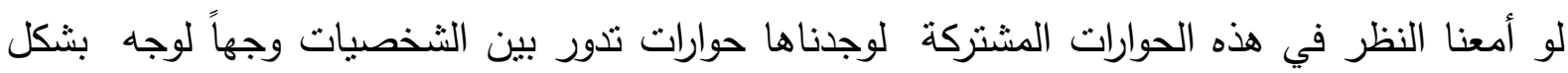

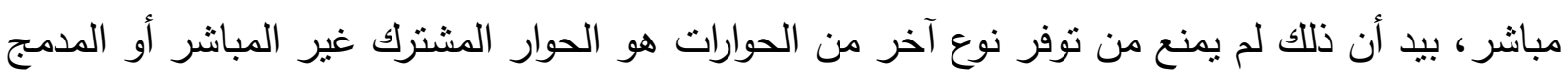

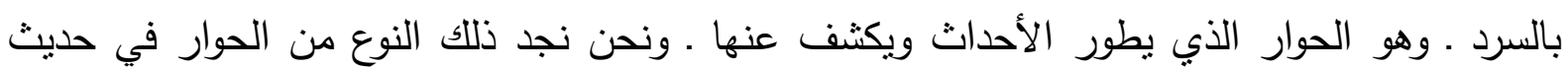
البطل مع الوالي الإيطالي ، وكذلك حوار الراوي ـ الثاعر ـ والبطل عندما تقص البطل شخصية الراوي وراح يسرد المذكرات على لسان المروي له الذي هو الثناعر ، وهكذا نجد أن وظيفة هذه الحوارات هي لهي لهري تحريك الأحداث ، وهذا الثيء يجعل القصة تقترب من الدراما . وبعد ، فان هذا هو ما لمسناه في سرد المهدوي من طرائق للبناء الفني القصصي ، ولكن ينبغي التتبيه هنا إلى أن اتساع رؤية المنهج المتبع جعلتنا نستغني عن دراسة عناصره كلها ، لاتساعها وضيق المقام ، بيد أننا حاولنا قدر المستطاع ان نعطي المهدوي حقه لأننا على يقين من أن هذه الطرائق ليست اعتباطية ، حتى لو لم تصدر عن مقصدية أو عمد ، ذلك لان هذه الطرائق تتطوي على دلالات تفسر

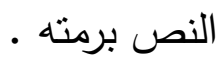

وختاماً نقول ؛ إن شعرية هذا النص وفرادته على المستوى الثكلي أو الهيكلي متأنية من بنية حدثه الافتتاحي ، عندما امسك الثاعر بحدث يسجل زمناً لاحقاً لبدء الحكاية ، هذا فضلاً عن استبعاب 
بنية العنوان لبنية النص كاملة ـ أما شعرية النص فرادته على المستوى الدلالي ، فهي منأنية من توظيف السرد ، فالثاعر هنا قد اكسب ذاتيته طابعاً موضوعياً وجعلنا ـ نحن القراء ـ نتعامل مع قضية الاستعمار بوصفه معتدياً ظالماً نظراً للمعطيات التي أفضى إليها السرد . 


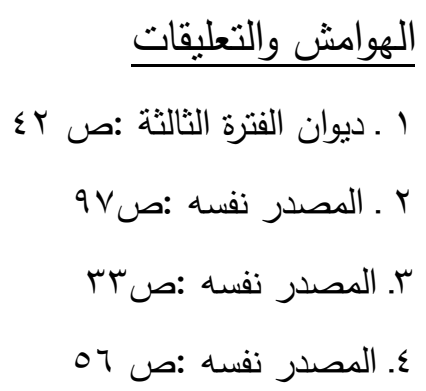

ه ـ للاستزادة من موضوع حياه الثاعر وظروفه ينظر : بحث الدكتور طه الحاجري المقدم الى مهرجان رفيق الادبي الذي اقامته الجامعة الليبية في ع.ب/ ديسمبر / (9V1 ، وكان بعنوان ( رفيق في مرحل حياته الأولى 191191 - 19r0 ) ونشرته مع بحوث ذلك المهرجان جامعة قار يونس في بني غازي في كتاب ( مهرجان رفيق الادبي ) عام سو 199 باشراف الاستاذ الدكتور محمد دغيم ، كما ينظر مقدمة ديوانه للفترة الاولى والثانية باشراف لجنة الرفيقيات من 1911 الى سنة هب 19 ، طا ، بنغازي ب971 ، ، وينظر كذلك : اعلام ليبيا . الطاهر احمد الزاوي الطرابلسي ، مؤسسة الفرجاني

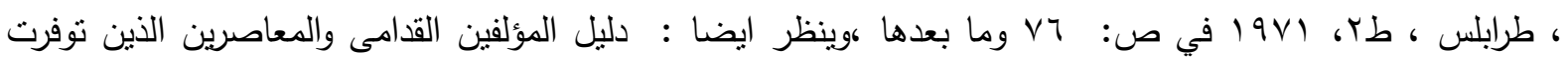
معلومات عنهم منذ الفتح الاسلامي لليبيا حتى سنة 19V7 ، مجموعة من المؤلفين ، دار الكتابة ، طرابلس ، I9VV : صساء وما بعدها ، وينظر كذلك : الثعر والثعراء في ليبيا ـ محمد الصادق عفيفي ، دار الطباعة الحديثة ، القاهرة ، 190V ، ص ب : 107 وما بعدها ، وينظر كذلك دراسة للباحث حسين بوشعالة نشرتها جريدة مصر الجديدة في http://www.misrelgdida.com/index.php?news $=3950$ r. . . $/ 9 /$ r I ـ ينظر على سبيل المثال : شاعر الوطن الكبير ، احمد رفيق المهدوي بين شعراء النضال في الادب العربي الحديث. محمد حامد الخضري ، رابطة الادب الحديث ، (1991 ، القاهرة . V ـ ينظر للاستزادة : صدى الجهاد الليبي في الادب الشعبي ـ محمد سعيد القشاط ، دار لبنان للطبع والنشر ، بيروت ، طا ، • 198 ، ص : 19. A ـ ينظر : جذور القومية العربية في الثعر الليبي المعاصر . نجم الدين غالب الكيب ، طا ، الدار العربية للكتاب ، طرابلس ، 19AV : ص • r وما بعدها ، الثعر الحديث في ليبيا ، دراسة في اتجاهاته وخصائصده . عوض محمد الصالح

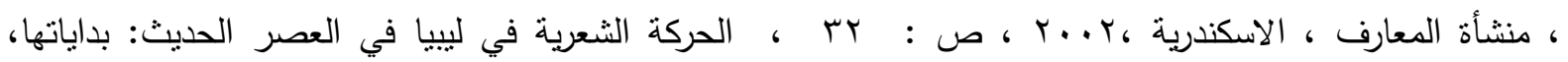
اتجاهاتها، قضاياها، أشكالها، أعلامها ـ قريرة زرقون نصر ، دار الكتاب الجديد المتحدة كبنغازي ، طا ، ع ... ، : 
ينظر : وفي الباب الثاني الذي رصد المؤلف فيه المسارات المختلفة والاتجاهات المنباينة التي برزت على ساحة المشهد الثعري في ليبيا، وكيف تفاعلت هذه الاتجاهات مع مراحلها بالقدر نفسه الذي انفتحت فيه على محيطها الخاص وعلى المحيط العربي والعالمي ، وينظر كذلك : الاتجاهات الوطنية في الثعر الليبي الحديث ـ محمد الصادق عفيفي ، بيروت ،

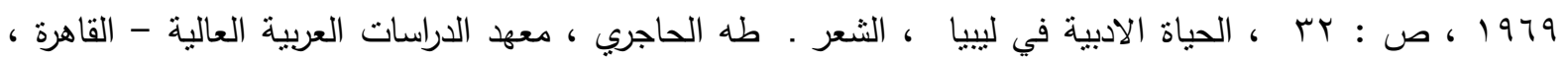
با7197 ، ص : ؟9 ، ، وينظر ايضا : جوانب مضيئة من الشعر العربي الليبي . محمد عبد الغني حسين ، المطبعة

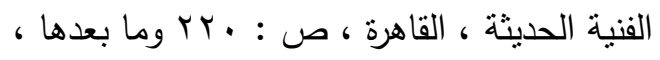
9 ـ ينظر على سبيل المثال : رفيق شاعر الوطن ، دراسة عن الثاعر الليبي احمد رفيق المهدوي والحركة الادبية الحديثة بليبيا ـ خليفه التليسي ، الدار العربية للكتاب ، طرابلس ، 1911 ، رفيق شاعر الوطنية والمجتمع ـ محمد الصادق عفيفي ، مكتبة الانجلو المصرية ، القاهرة ، 1909 ، رفيق في الميزان ، دراسة وتحليل لشعر احمد رفيق المهدوي . عبد ربه الغناي ، مكتبة الاندلس ، بنغازي ، طا ، 197 ، الشاعر الوطن الكبير ، احمد رفيق المهدوي بين شعراء النضال في الادب العربي الحديث ـ محمد حامد الحضيري، رابطة الادب الحديث ، القاهرة ، 1991 ،وينظر كذلك رسالة الماجسنير من جامعة القاهرة للباحث عبد مولى البغدادي الموسومة : احمد رفيق المهدوي شاعر ليبيا في العصر الحديث ،وله كذلك دراسة بعنوان ( نظرات في شعر رفيق ) وردت في كتاب ( مهرجان رفيق الادبي ) ، ص : جrr ، وينظر كذلك : اعلام

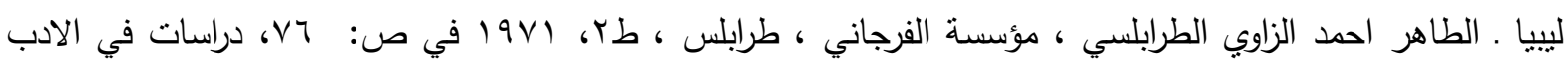
الحديث . بشير الهاشمي محمد الباهي ،الدار العربية للكتاب ، 19V9 ، ص ص : 97 وما بعدها ، الحياة الأدبية في ليبيا -

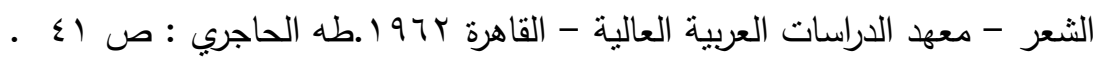
• ـ ـ ديوان احمد رفيق المهووي ـ الفترة الثالثة : ص ع ا وما بعدها ، وتتبغي الاثارة هنا الى اغلب الباحثين قد نبهوا على اهمية هذه القصيدة مجال البناء القصصي عند المهدوي ، نذكر منهم على سبيل المثال : التصوير التاريخي في

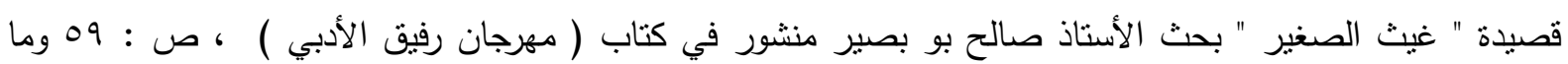

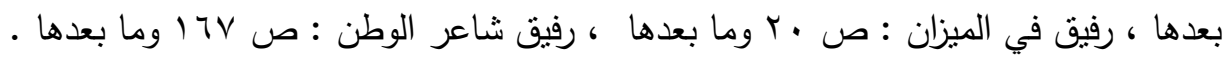
Iا ـ ينظر : اهمية الزمان في الفلسفة والادب ـ مدخل نظري ، دراسة للباحثة اسيا البو علي ، مجلة نزوى العمانية ،

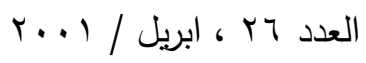


ז ا ـ يشير الباحث الدكتور فرج نجم : ان شخصية ( غيث ) هي شخصية حقيقية ، تلاعب الثاعر باسمه اذ استبدل اسم البطل الحقيقية لهذه القصة وهو ( ادريس ) بغيث، لما لأسمه - إدريس - من تبعات وتداعيات سياسية بالأمير إدريس السنوسي، يعاقب عليها الفاشست، إذا ما ذكرت أو حدثت ، ويضيف الباحث ان ادريس هذا كان من أشهر أبطال الملاجئ في ليبيا إبان الاحتلال الإيطالي ، فقد كان الطفل إدريس علي امغيب (هذا هو اسمه الكامل وكان من قبيلة العواقير في منطقة بنغازي)، قد أدخل إلى معتقل العقيلة في سن السابعة مع أسرته المكونة من أمه فضيلة، وأخيه جبريل، وأخته عائشة، ضمن خطة إيطاليا القاضية بإيداع أسر المجاهدين في معتقلات صحراوية مهلكة، وذلك للضغط على حركة الجهاد ، نقل الطفل إدريس إلى الملجأ بعد أن مات جميع أفراد أسرته من المرض والجوع بمعتقل العقيلة، وكان والده علي امغيب مجاهدا حضر الكثير من الملاحم أثنرها يوم القرضابية، التي اجتمعت فيها قبائل ليبيا المجاهدة وهزمت القوات الإيطالية هزيمة نكراء عام 19 (ام، وقد استشهد الوالد علي قرب "الثشبردق" (الأسلاك الثائكة) على الحدود المصرية الليبية، عندما كان بصحبة الثيخ القائد عبد الحمبد العبار، حيث كان المحافظية (المجاهدون) يقاتلون ببسالة معركتهم الأخيرة، بعد إعدام شيخ الثهداء عمر المختار في 17 سبتمبر اسبو (م. وجد الطفل إدريس نفسه في الملجأ - يعرف بالإيطالية بـ الكوليدجو - بمنطقة المقرون، يدرس اللغة الإيطالية، ويتدرب على أعمال الكثافة الإيطالية

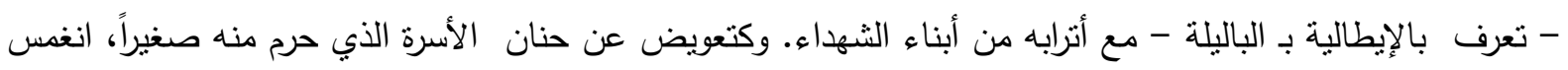
الطفل إدريس في تعلم اللغة الإيطالية، وإنقان النشاطات الكثفية، حتى أصبح في سن التاسعة رئيساً لفريق الاستعراض الكثفي بالملجأ. أما حبه الكبير فقد كان لبندقية صنعها له مدرس التربية المهنية من الخشب كانت لا تفارقه طبلة يومه ، وعندما زار ملك إيطاليا امانويل، صحبة الماريشال دي بونو، والجنرال غراتسياني، ملجأ المقرون في الأول من يونيو عام بس 9 (ام، والجنرال غرانسياني عرف بـ "سفاح ليبيا" لما قام به من جرائم وحشية توجها في ليبيا بإعدام رمز الجهاد عمر المختار، فإلتقي الملك بالطفل إدريس، الذي كان يقود فرقة الاستعراض الكثفي، حاملاً بندقيته الخشبية لتحية الملك ومرافقيه. وقدم مشرف الملجأ الطفل إدريس كنموذج حي على دمج الليبيين في الثقافة الفانشيسنية، حيث كان بتحدث الإيطالية بفصاحة تثير الدهثة بالنسبة لعمره، ويحفظ الثعر الإيطالي عن ظهر قلب. وعندما انتهى الملك وغراتسياني من الإستماع إلى مجموعة من القصائد والأناشيد الإيطالية التي كان يرددها الطفل من ذاكرته، أمر غراتسياني - أمام الصحافة من باب الدعاية المغرضة - بإعطاء الطفل إدريس جائزة قدرها ـه فرنكاً، وما أن مد إدريس يده ليستلم النقود حتى بادر غراتسياني بسؤاله عن أمنيته، وعما سيفعل بالنقود، فأخبره الطفل بالإيطالية بأنه بريد شراء بندقية حقيقية بدلا لإلاهل 
من بندقية الخشب، ويقتل من قتل أباه. فأله غراتسياني بخبث عمن قتل أباه. هنا تدخل معلمه، عبد الرازق شقلوف، وهمس باللغة العربية قل لهم: المحافظية .. المحافظية، أب يقصد المجاهدين. هذه البراءة لم يفهمها غراتسياني ورهطه، إلا في الحرب العالمية الثانية، عندما تحين الثاب إدريس على الفرصة، إثز دخول قوات الحلفاء بقيادة بريطانيا إلى بنغازي، حيث انضم إلى مجموعات من شباب المدينة التي كانت تهاجم فلول الطليان المنسحبة، وتثأر من جرائمهم. وبعد أنشر قليلة إنضم إدريس لقوات جيش التحرير الليبي، الذي كان يعرف بالجيش السنوسي، الذي كان يقاتل إلى جانب الجيش الثامن البريطاني، حيث شارك إدريس في معركة حصار طبرق، والزحف على بنغازي لتحريرها من قتلة والده وأسرته ، وإثر تحرير ليبيا منح إدريس علي وسام ميدالية جيش التحرير السنوسي من قبل الأمير إدريس السنوسي، وكذلك وسام نجمة شمال أفريقيا من ملك بريطانيا ،نظر : مدونة جولات في التاريخ الليبي http://historylibya.blogspot.com/2013/01/blog-post_3.html) با ـ ينظر : السيميولوجيا بقراءة رولان بارت ـ د. وائل بركات ، مجلة جامعة دمشق - المجلد 11 - العدد الثنانيTr: ـا ـ ينظر : عودة الى خطاب الحكاية ، جيرار جينيت، ، ت : محمد معتصم ، المركز الثقافي العرب، . ... ب، الدار 9 البيضاء كص : 19 . 19

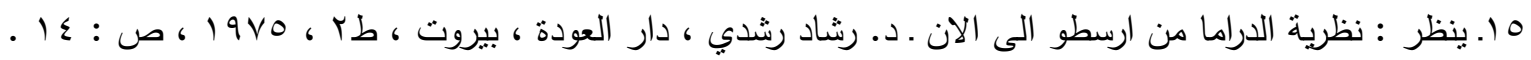
17 ـ ـينظر : الاحساس بالنهاية . دراسات في نظرية القصة ، البروفسور فرانك كرمود ، ت: د. عناد غزوان اسماعيل وجعفر صادق الخليلي ، دار الرشيد للنشر ، بغداد ، 9 199 ، ص سب . V ا ـ ينظر : الاسس النفسية لاساليب البلاغة العربية ،د. مجيد عبد الحميد ناجي ، المؤسسة الجامعية للدراسات والنشر ،

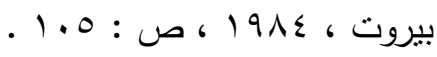
11 ـ ينظر : الاحساس بالنهاية . دراسات في نظرية القصة ، البروفسور فرانك كرمود ، ت: د. عناد غزوان اسماعيل

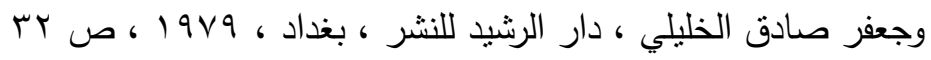
9 ا ـ ينظر : قضايا الفن القصصي ، الدذهب واللغة والنماذج البشرية ـ. د. يوسف نوفل ، المطبعة العربية الحديثة ،

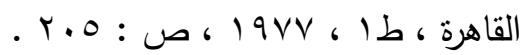
. r ـ العنكبوت . اية : 7 . 


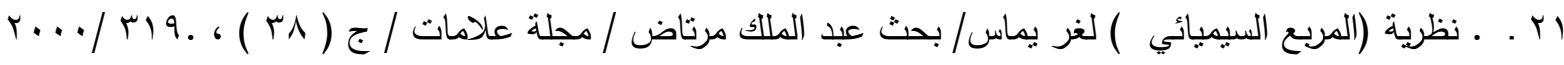
ץ ب ـ ينظر : مدخل لدراسة الرواية ، جيريمي هونورك ، ت: غازي درويش عطية ، مراجعة : د ـ سلمان داود الواسطي ، دار الثؤون النقافية العامة ، بغداد ، 1997 ، ص : ك V . بr ـ ينظر : النص الغائب ، دراسة في جدلية العلاقة بين النص الحاضر والنص الغائب ، احمد الزغبي ، م ـ ابحاث اليرموك ، سلسلة الآداب واللغويات ، عمان ، العدد ا ، ـ991 ، ص : 9r . . ع ب ـ ينظر : تحليل الخطاب الروائي ، سعيد يقطين ، المركز الثقافي العربي ، بيروت ، طا ، 1919 ، ص : V7 . ه . نظر :الرواية البوليفونية أو الرواية المتعددة الأصوات ، د. جميل حمداوي ، شبكة الالوكة الثقافية ، /http://www.alukah.net/Publications_Competitions/11096/39038 جب ـ ينظر : المروي له في درجة الصفر داخل السرد ، د ـ عمر محمد الطالب ، م ـ آداب الرافدين ، جامعة الموصل ، كلية الآداب ، العدد Y ، ، 1997 ، ص : .ـ . Y rV . ينظر : مقولات السرد الأدبي ، تزفتان تودوروف، ت : الحسين سحبان وفؤاد صفا، مشورات إتحاد كتاب المغرب، الرباط، طا ،و991، ص (7 ، ، وينظر كذلك : المتخيل السردي ، عبد الله ابراهيم ، المركز الثقافي العربي، بيروت،

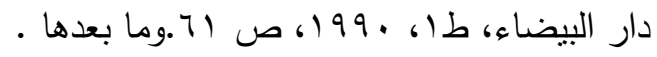
^ץ ـ ينظر : الوصف بين الثعر والسرد ، عبد الكريم خضير عليوي السعيدي ، م ـ آداب ذي قار ، العدد ب، المجلد

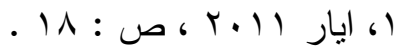
9ץ ـ ينظر للاستزادة: الحوار القصصي، فاتح عبد السلام، المؤسسة العربية للاراسات والنشر، بيروت، ط ب، ب191)، ص 


\section{المصادر}

- القرآن الكريم

1- الاتجاهات الوطنية في الثعر الليبي الحديث ـ محمد الصادق عفيفي ، بيروت ، 1979 ، 1979 ץ- الاحساس بالنهاية ـ دراسات في نظرية القصة ، البروفسور فرانك كرمود ، ت: د. عناد غزوان اسماعيل وجعفر صادق

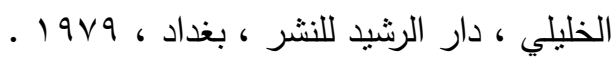

r- الاسس النفسية لاساليب البلاغة العربية ،د. مجيد عبد الحميد ناجي ، المؤسسة الجامعية للاراسات والنشر ، بيروت ،

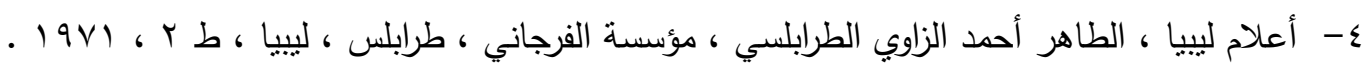
ه ـ اهمية الزمان في الفلسفة والادب ـ مدخل نظري ، دراسة للباحثة اسيا البو علي ، مجلة نزوى العمانية ، العدد جب ،

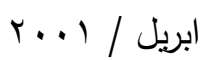
צ- تاريخ الحركة النقافية فى ليبيا إبان الاحتلال الايطالى ، دراسة للباحث حسين بوشعالة نشرتها جريدة مصر الجديدة

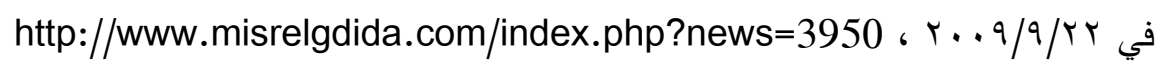

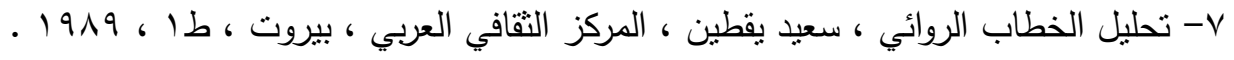
^- جذور القومية العربية في الثعر الليبي المعاصر ـ نجم الدين غالب الكيب ، طا ، الدار العربية للكتاب ، طرابلس ، : 191 V

9- جوانب مضيئة من الثعر العربي الليبي ـ محمد عبد الغني حسين ، المطبعة الفنية الحديثة ، القاهرة • 1- الحركة الثعرية في ليبيا في العصر الحديث: بداياتها، اتجاهاتها، قضاياها، أثنكالها، أعلامها ـ قريرة زرقون نصر ،

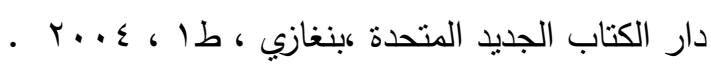
11 - الحوار القصصي، فاتح عبد السلام، المؤسسة العربية للاراسات والنشر، بيروت، ط ب، ب 1919 ـ r ا - الحياة الادبية في ليبيا ، الثعر · طه الحاجري ، معهد الدراسات العربية العالية - القاهرة ، ب79 19 ـ

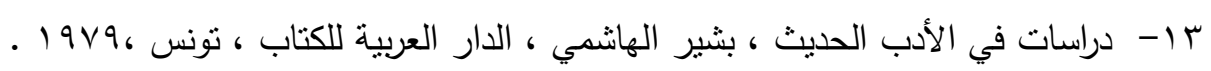
ع ا- دليل المؤلفين القدامى والمعاصرين الذين توفرت معلومات عنهم منذ الفتح الاسلامي لليبيا حتى سنة $19 V 7$ ، مجموعة من المؤلفين ، دار الكتابة ، طرابلس ، I YVV . 
10- ديوان أحمد رفيق المهدوي ، الفترة الأولى والثانية ، من 1919 الى 19ro ، إثراف لجنة الرفيقيات ، ط 1 ، بنغازي ، 1974

7 ا - رفيق شاعر الوطن ، دراسة عن الثاعر الليبي احمد رفيق المهدوب والحركة الادبية الحديثة بليبيا . خليفه التليسي ، الدار العربية للكتاب ، طرابلس ، 1911 . 191

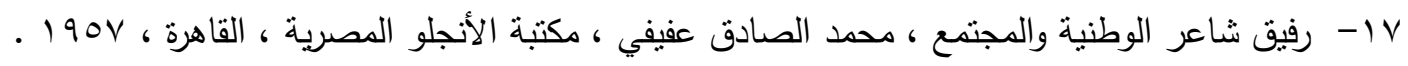
1ا- رفيق في الميزان ، دراسة وتحليل لشعر رفيق المهدوي ، عبد ربه الغناي ، منشورات مكتبة الأندلس ، بنغازي ، ط ط .1978 .1

9 ا - الرواية البوليفونية أو الرواية المتعددة الأصوات ، د. جميل حمداوي ،مدونة شبكة الالوكة الثقافية الاككترونية ، /http://www.alukah.net/Publications_Competitions/11096/39038

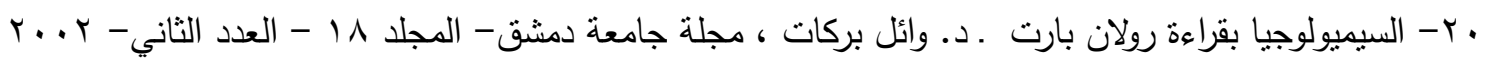
اب- شاعر الوطن الكبير ، احمد رفيق المهدوي بين شعراء النضال في الادب العربي الحديث ـ محمد حامد الخضري ، رابطة الادب الحديث ، 1991 ، القاهرة . Yr- الثعر الحديث في ليبيا ، دراسة في اتجاهاته وخصائصه ، عوض محمد الصالح ، منشأة المعارف ، الاسكندرية

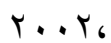
بr- الثعر والثعراء في ليبيا ، محمد الصادق عفيفي ، دار الطباعة الحديثة ، القاهرة ، 190V.

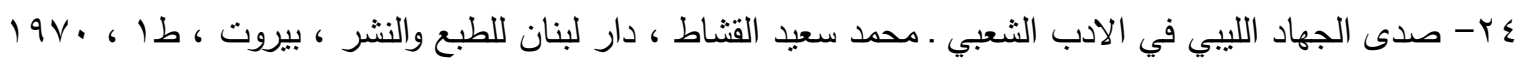
هץ- عودة الى خطاب الحكاية ، جيرار جينيت، ، ت : محمد معتصم ، المركز التقافي العربي، .... ؟، الدار البيضاء جب- الغيث الصغير الذي بهر الملك وقهر الفانشت...د.فرج نجم ، دراسة منشورة على مدونة جولات في التاريخ الليبي ، http://historylibya.blogspot.com/2013/01/blog-post_3.html)

V V- قضايا الفن القصصي ، المذهب واللغة والنماذج البشرية ـ د. يوسف نوفل ، المطبعة العربية الحديثة ، القاهرة ، طا $.19 V V_{6}$ 1ץ- المتخيل السردي ، عبد الله ابراهيم ، المركز الثقافي العربي، بيروت، دار البيضاء، طا، ـ9919 ـ 
وץ- - مدخل لدراسة الرواية ، جيريمي هونورك ، ت: غازي درويش عطية ، مراجعة : د ـ سلمان داود الواسطي ، دار

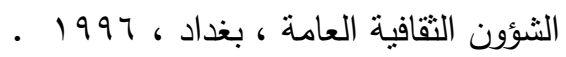
• ب- المروي لله في درجة الصفر داخل السرد ، د ـ عمر محمد الطالب ، م ـ آداب الرافدين ، جامعة الموصل ، كلية

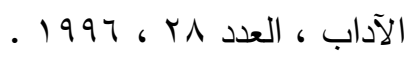
اس- مقولات السرد الأدبي ، تزفتان تودوروف، ت : الحسين سحبان وفؤاد صفا، مشورات إتحاد كتاب المغرب، الرباط، . 1994.

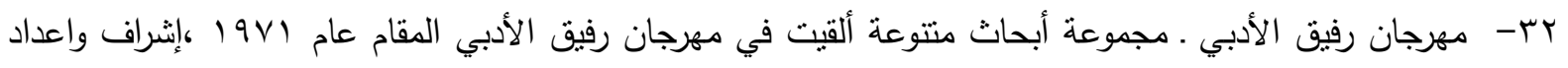

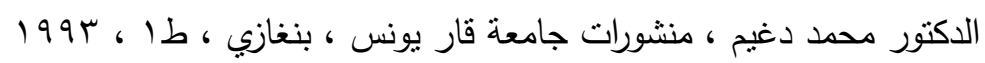
rr- النص الغائب ، دراسة في جدلية العلاقة بين النص الحاضر والنص الغائب ، احمد الزغبي ، م ـ ابحاث اليرموك ،

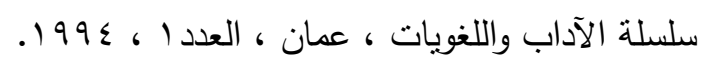

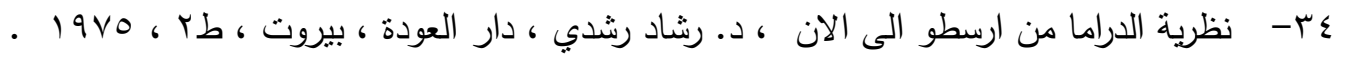

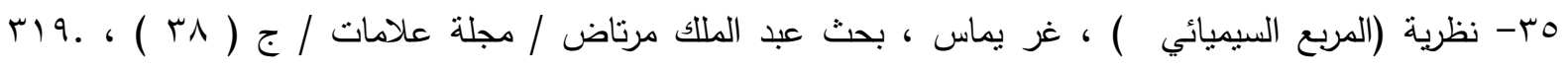
r.../ جr- الوصف بين الثعر والسرد ، عبد الكريم خضير عليوي السعيدي ، م ـ آداب ذي قار ، العدد ז، الدجلد ا، ايار 